\title{
Neurovascular unit dysfunction with blood-brain barrier hyperpermeability contributes to major depressive disorder: a review of clinical and experimental evidence
}

\author{
Souhel Najjar ${ }^{1,2^{*}}$, Daniel M Pearlman ${ }^{1,3}$, Orrin Devinsky², Amanda Najjar ${ }^{4}$ and David Zagzag ${ }^{4,5}$
}

\begin{abstract}
About one-third of people with major depressive disorder (MDD) fail at least two antidepressant drug trials at 1 year. Together with clinical and experimental evidence indicating that the pathophysiology of MDD is multifactorial, this observation underscores the importance of elucidating mechanisms beyond monoaminergic dysregulation that can contribute to the genesis and persistence of MDD. Oxidative stress and neuroinflammation are mechanistically linked to the presence of neurovascular dysfunction with blood-brain barrier (BBB) hyperpermeability in selected neurological disorders, such as stroke, epilepsy, multiple sclerosis, traumatic brain injury, and Alzheimer's disease. In contrast to other major psychiatric disorders, MDD is frequently comorbid with such neurological disorders and constitutes an independent risk factor for morbidity and mortality in disorders characterized by vascular endothelial dysfunction (cardiovascular disease and diabetes mellitus). Oxidative stress and neuroinflammation are implicated in the neurobiology of MDD. More recent evidence links neurovascular dysfunction with BBB hyperpermeability to MDD without neurological comorbidity. We review this emerging literature and present a theoretical integration between these abnormalities to those involving oxidative stress and neuroinflammation in MDD. We discuss our hypothesis that alterations in endothelial nitric oxide levels and endothelial nitric oxide synthase uncoupling are central mechanistic links in this regard. Understanding the contribution of neurovascular dysfunction with BBB hyperpermeability to the pathophysiology of MDD may help to identify novel therapeutic and preventative approaches.
\end{abstract}

Keywords: Major depressive disorder, Blood-brain barrier, Neurovascular unit, Neuroinflammation, Oxidative stress, Nitric oxide synthase, eNOS uncoupling, Peroxynitrite

\section{Background}

Major depressive disorder (MDD) is the second leading global cause of years lived with disability [1], with about one-third of patients with MDD failing two or more conventional antidepressant drug trials within the first year of treatment $[2,3]$. Current evidence suggests that the pathophysiology of MDD is multifactorial, involving heterogeneous and inter-related mechanisms that affect

\footnotetext{
* Correspondence: mna1024231@aol.com

'Department of Neurology, Neuroinflammation Research Group, Epilepsy Center Division, NYU School of Medicine, New York, NY 10016, USA ${ }^{2}$ Department of Neurology, NYU Comprehensive Epilepsy Center, NYU School of Medicine, New York, NY 10016, USA

Full list of author information is available at the end of the article
}

genetic, neurotransmitter, immune, oxidative, and inflammatory systems [4]. Supporting this interpretation, whereas biomarkers for individual abnormalities possess limited predictive validity for MDD, the predictive validity of several composite biomarker assays is particularly high [5]. For example, one study of 36 patients with MDD showed that a compositive biomarker test-comprising nine individual biomarker assays ( $\alpha 1$ antitrypsin, apolipoprotein CIII, myeloperoxidase, soluble tumor necrosis factor $\alpha$ (TNF $\alpha$ ) receptor type II, epidermal growth factor, cortisol, brain-derived neurotropic factor, prolactin, and resistin) - had 91.7\% sensitivity and $81.3 \%$ specificity for MDD [6]. A follow-up study involving a distinct sample of $34 \mathrm{MDD}$ patients and using the same 
composite assay, replicated these results with a high degree of precision: $91.1 \%$ sensitivity, $81.0 \%$ specificity [6].

Oxidative stress and neuroinflammation are implicated in the neurobiology of MDD [7-14] (recently reviewed by our group [4,15-19]). Neuropathological studies comparing brain tissue from individuals with MDD to that from non-depressed controls have documented associations between MDD and (a) decreased levels of antioxidants, such as glutathione $[11,15,16]$ and (b) increased levels of lipid peroxidation end products, such as 4hydroxy-2-nonenal [8]. Studies assessing peripheral markers of oxidative stress have reported similar findings, including: (a) altered activity of antioxidant enzymes, such as glutathione peroxidase, catalase, superoxide dismutase 1 , (b) increased activity of pro-oxidant enzymes such as, xanthine oxidase, (c) increased activity of inducible nitric oxide synthase (iNOS) in leukocytes, (d) increased levels of superoxide $\left(\mathrm{O}_{2}^{-}\right)$, and (e) increased levels of 8-hydroxy-2-deoxyguanosine (a marker for oxidative damage to DNA) [11,12]. Evidence deriving from genetic, neuropathological, cerebrospinal fluid, and serum studies in humans with MDD and from animal models of depressive-like behavior and chronic stress reveal numerous neuroinflammatory abnormalities in MDD, including [4]: (a) microglial activation [17-19], (b) astroglial loss and activation [20,21], (c) upregulated ratios of $\mathrm{T}$ helper 1 (Th1) cells and proinflammatory cytokines [22-24], and (d) decreased $\mathrm{CD} 44^{+} \mathrm{CD} 25^{+} \mathrm{FOXP} 3^{+}$regulatory $\mathrm{T}$ $\left(\mathrm{T}_{\mathrm{Reg}}\right)$ cell counts [25]. Both oxidative stress and neuroinflammation may contribute to decreased serotonergic and increased glutamatergic tone, and increased glutamatergic tone may in turn contribute to oxidative stress and neuroinflammation in a positive feedback loop [4]. In addition, experimental evidence suggests that increased reactive oxygen species (ROS) synthesis (oxidative stress) and neuroinflammation themselves exhibit a bidirectional relationship (Figure 1). Indeed, ROS can activate microglia and increase proinflammatory cytokine synthesis-for example,

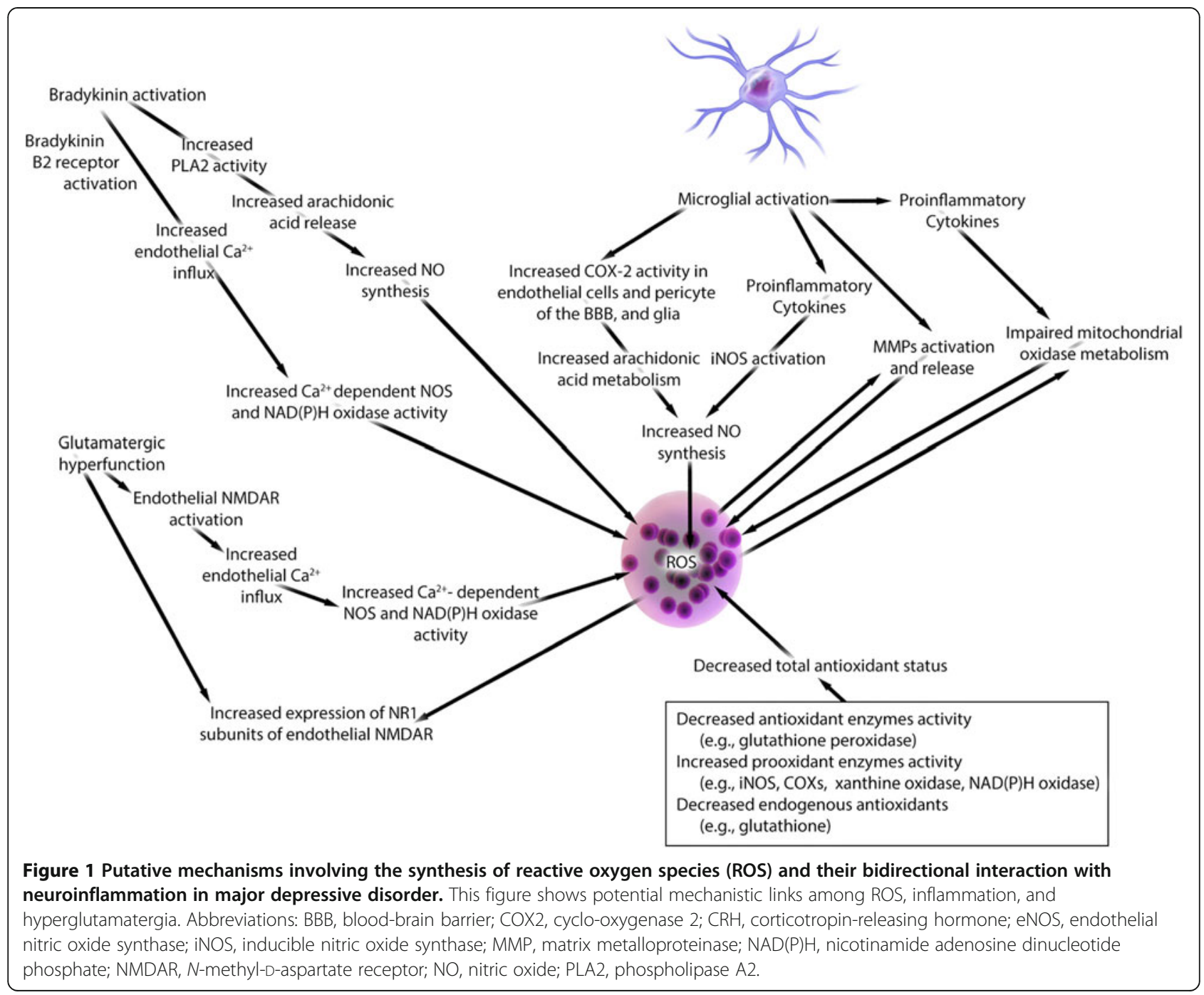


by stimulating transcription factor nuclear factor $\mathrm{kB}$ $(\mathrm{NF \kappa B})$ - whereas activated microglia and proinflammatory cytokines can in turn perpetuate oxidative stress [8,11,26-28].

Collectively, data from postmortem neuropathological human studies and in vivo neuroimaging human and animal studies provide strong evidence of neurovascular unit dysfunction with blood-brain barrier (BBB) hyperpermeability in association with oxidative stress and neuroinflammation in selected neurological disorders, such as stroke, epilepsy, Alzheimer's disease, traumatic brain injury, and multiple sclerosis [29-43] (Table 1). In these disorders, BBB breakdown, oxidative stress, and inflammation are thought to impair neuronal function [44]. MDD, in contrast to other major psychiatric disorders, is frequently comorbid with such neurological disorders as well as disorders characterized by vascular endothelial dysfunction, such as cardiovascular disease and diabetes mellitus [45-52]. Whether neurovascular dysfunction with $\mathrm{BBB}$ hyperpermeability occurs in primary MDD (without neurological comorbidity), however, remains less clear.

Shalev and colleagues have previously reviewed evidence through 2009 linking BBB hyperpermeability to psychiatric disorders generally [168]. We review emerging clinical and experimental evidence implicating oxidative stress, eNOS uncoupling, and reduced endothelial NO levels in the pathophysiology of peripheral vascular endothelial dysfunction associated with MDD. We present a theoretical integration of human and animal data linking these mechanisms and those involving neuroinflammation to findings suggesting that neurovascular dysfunction can occur in primary MDD. We also discuss putative links between neurovascular

Table 1 Putative mechanisms of neurovascular dysfunction and blood-brain barrier hyperpermeability in major depressive disorder in the context of established mechanisms in various neurological disorders

\begin{tabular}{|c|c|c|c|c|c|c|}
\hline \multirow[t]{2}{*}{ Mechanisms } & \multicolumn{4}{|c|}{ Major depressive disorder } & \multicolumn{2}{|c|}{ Neurological disorders } \\
\hline & Human & Sources & Animal & Sources & Human & Sources \\
\hline \multicolumn{7}{|l|}{ Oxidative stress } \\
\hline eNOS uncoupling, decreased NO & - & [53-59] & - & {$[60]$} & $\bullet$ & {$[61-63]$} \\
\hline Increased ROS synthesis & $\bullet$ & {$[10,14-16,64-84]$} & $\bullet$ & {$[64,85]$} & $\bullet$ & {$[42,63,86]$} \\
\hline Cerebral hypoperfusion & $\bullet$ & {$[87-91]$} & $N / A$ & $\ldots$ & $\bullet$ & {$[92-96]$} \\
\hline MMP activation & $\mathbf{\square}$ & {$[97]$} & $?$ & $\cdots$ & $\bullet$ & {$[39,42,98-101]$} \\
\hline Decreased E-cadherin activity & $?$ & $\ldots$ & $?$ & $\ldots$ & $?^{\mathrm{a}}$ & {$[38,102]$} \\
\hline Tight junction alteration & $?$ & $\ldots$ & $?$ & $\ldots$ & $\bullet$ & {$[31,38,41,103-106]$} \\
\hline Endothelial cytoskeletal alteration & $?$ & $\ldots$ & $?$ & $\ldots$ & $\bullet$ & {$[31]$} \\
\hline Increased NMDAR expression ${ }^{b}$ & 0 & {$[107-111]$} & $\bullet$ & {$[40]$} & $\bullet$ & {$[112]$} \\
\hline Mitochondrial alterations & $\bullet$ & {$[65,113-121]$} & $\bullet$ & {$[65,122]$} & $\bullet$ & {$[11,123-125]$} \\
\hline \multicolumn{7}{|l|}{ Neuroinflammation } \\
\hline Astroglial loss & $\bullet$ & {$[20,21,126-133]$} & $\bullet$ & [134-138] & $\bullet$ & {$[139-141]$} \\
\hline Decreased AQP4 & $\bullet$ & {$[142]$} & $\bullet$ & {$[143]$} & $\bullet$ & {$[144-146]$} \\
\hline Microglial activation & $\bullet$ & {$[18,147,148]$} & $\bullet$ & {$[149-152]$} & $\bullet$ & {$[42,98,153,154]$} \\
\hline Proinflammatory cytokines & $\bullet$ & {$[23,155]$} & $\bullet$ & {$[156,157]$} & $\bullet$ & {$[42,98]$} \\
\hline Bradykinin alteration & $\bullet$ & {$[158]$} & $\bullet$ & [159] & $\bullet$ & {$[159,160]$} \\
\hline Hyperglutamatergia & $\bullet$ & {$[4,161-163]$} & $\bullet$ & {$[164]$} & $\bullet$ & {$[165-167]$} \\
\hline Mast cell activation & $\bullet$ & {$[168,169]$} & $?$ & $\ldots$ & $\bullet$ & {$[170,171]$} \\
\hline Increased ICAM-1 and VCAM-1 & 0 & [172-174] & $?$ & $\ldots$ & $\bullet$ & [175-178] \\
\hline \multicolumn{7}{|l|}{ Other mechanisms } \\
\hline Increased P-glycoprotein activity & $\bullet$ & {$[179,180]$} & $\bullet$ & {$[181]$} & $\bullet$ & [179] \\
\hline
\end{tabular}

Symbol key: $\bullet$, documented in the central nervous system in major depressive disorder; $\mathbf{\square}$, not documented in the central nervous system, but associated with major depressive disorder; ?, insufficient data; $\mathbf{O}$, mixed evidence.

Abbreviations: $A Q P 4$, aquaporin 4; eNOS, endothelial nitric oxide synthase; ICAM-1, intercellular adhesion molecule 1; NMDAR, N-methyl-D-aspartate receptor; $M M P$, matrix metalloproteinases; ROS, reactive oxygen species; VCAM-1, vascular cell adhesion molecule 1.

a. Refers to data that has only been shown in animal models.

b. Refers to human data in major depressive disorder refers to increased NMDAR expression that was not specific to the endothelium. Human data of NMDAR subunit composition alteration in neurological disorders was shown in cultured human blood-brain barrier endothelial cells. Animal data refer to increased cerebrovascular endothelial NMDAR subunit 1 (NR1) expression upon exposure to oxidative stress (this was not a depressive-like behavior or chronic stress animal model, though this evidence may be relevant to MDD where oxidative stress is documented).

c. Refers to abnormalities for which only limited data exists. 
dysfunction with BBB hyperpermeability and neuronal signaling abnormalities in MDD.

\section{Neurovascular unit dysfunction}

The neurovascular unit consists of cerebral microvessels, glial cells (astroglia, microglia, oligodendroglia), and neurons. It is the epicenter of several tightly controlled, dynamic, and complex cellular interactions between glia and neurons, and the coupling of neuronal activity with endothelium-dependent cerebral blood flow [33]. Evidence of an association between MDD and neurovascular dysfunction is indirect, deriving primarily from studies assessing peripheral vascular endothelial dysfunction in MDD and from epidemiological data associating MDD with vascular disorders.

One method for evaluating endothelial dysfunction involves measuring the relative uptake ratio (RUR) of blood flow in the brachial artery after hyperemic challenge via dynamic nuclear imaging. RUR is a measure of the vascular dilatory response whereby a lower RUR implies poorer vascular endothelial function. In a prospective cohort involving 23 patients with MDD, 23 with minor depressive disorder, and 277 non-depressed controls, the mean RUR was significantly lower in participants with MDD (unadjusted mean $=3.13, \mathrm{SD}=1.51$ ) or minor depressive disorder (unadjusted mean $=3.38$, $\mathrm{SD}=1.00)$ compared with non-depressed controls (unadjusted mean $=4.22, \mathrm{SD}=1.74)(F=6.68, P=0.001)$ [182]. This effect remained statistically significant after adjusting for age, sex, socioeconomic factors, medical comorbidity, and medications $(F=5.19, P=0.006)$ [182]. One study evaluating endothelial proapoptotic activity, defined as the percentage of apoptotic nuclei in human umbilical vein endothelial cells, found a significantly increased percentage of proapoptotic nuclei in participants with MDD compared with non-depressed controls $(4.4 \%$ vs $2.3 \%, P \leq 0.001)$ [183]. This finding remained statistically significant after adjusting for age and cardiovascular comorbidity.

Linking vascular endothelial dysfunction to MDD, epidemiological studies reveal a strong and bidirectional association between MDD and medical conditions characterized by vascular endothelial pathology [184]. A recent meta-analysis involving 16,221 study participants found a significantly increased risk of MDD among individuals with major vascular diseases compared with those without vascular disease: diabetes (odds ratio (OR) $1.51,95 \%$ confidence interval $(\mathrm{CI}) 1.30$ to $1.76, P<$ $0.0005,15$ studies), cardiovascular disease (OR 1.76, 95\% CI 1.08 to $1.80, P<0.0005,10$ studies), and stroke (OR $2.11,95 \%$ CI 1.61 to $2.77, P<0.0005,10$ studies) [45]. The same meta-analysis also found that MDD was more common among individuals with two or more classic risk factors for vascular disease compared with those with one or no risk factors (OR 1.49, 95\% CI 1.27 to 1.7, $P<0.0005,18$ studies) [45]. These findings remained robust after statistical adjustments for chronic illness and disability. Results from meta-analyses having assessed the association from the reverse direction, indicate that MDD is not only an independent risk factor for cardiovascular disease (relative risk (RR) 2.69, 95\% CI 1.63 to $4.43, P<0.001,11$ studies) [49], but is also associated with a 3-fold increased cardiovascular disease mortality rate (OR 2.61, 95\% CI 1.53 to $4.47, P=0.0004$ ) [48]. Related studies report similar findings [50-52].

\section{Blood-brain barrier unit hyperpermeability}

The BBB consists of the neurovascular endothelium, extracellular matrix basal lamina, and astrocytic end-feet processes. The BBB secures the brain's immune-privileged status by restricting the entry of peripheral inflammatory mediators (for example, cytokines, antibodies), which can impair neurotransmission [37,168,185,186]. Neurovascular endothelial cells regulate influx of essential nutrients, efflux of toxic substances, ionic homeostasis of brain interstitial fluid, and prevent brain influx of peripheral neuroactive substances, neurotransmitters, and water-soluble molecules [185]. Evidence of an association between BBB hyperpermeability and MDD derives mainly from studies having assessed cerebrospinal fluid (CSF)-to-serum ratios of various molecules, as well as evaluations concerning P-glycoprotein.

Evidence of an elevated CSF-to-serum albumin ratio in some MDD patients is suggestive of mild hyperpermeability of blood-brain and/or blood-CSF barriers [186,187]. A cross-sectional study of elderly women without dementia (11 MDD, 3 dysthymia, 70 non-depressed controls) found an elevated mean CSF-to-serum albumin ratio among those with MDD or dysthymia relative to non-depressed controls $\left(7.1 \times 10^{-3}\right.$ vs $5.4 \times 10^{-3}$, age-adjusted $\left.P<0.015\right)$ [186]. Another study (24 affective disorders, 4,100 age-matched controls) found an increased mean CSF-to-serum albumin ratio among $37.5 \%$ of the affective disorder group (9 of 24); this value was $22 \%$ to $89 \%$ above the upper limit of healthy age-matched controls $\left(8.7 \times 10^{-3}\right.$ vs $\left.5.0 \times 10^{-3}\right)$ [187]. A third study (99 MDD) found that increased CSF-to-serum ratios of albumin and urate were positively associated with EEG slowing (a measure of cerebral dysfunction) and suicidality [188]. Elevated levels of S100B protein (a marker of glial activation) $[189,190]$ and proinflammatory cytokines $[23,191]$ in the serum, CSF, and neuropathological specimens from persons with MDD may be related to increased permeability of blood-brain and blood-CSF barriers. Elevated levels of these molecules may reflect their increased synthesis and increased efflux from (a) brain parenchyma into the blood (BBB hyperpermeability) [168,184], and (b) blood into the CSF (blood-CSF hyperpermeability). 
Alteration of BBB endothelial expression of Pglycoprotein (a multidrug efflux transporter) is documented in some persons with MDD [192]. Reduced expression or function of P-glycoprotein may facilitate BBB permeability to neurotoxic substances [192]. Positron emission tomography (PET) utilizing the [(11)C]verapamil radioligand for $\mathrm{P}$-glycoprotein in humans with MDD and in Wistar rats exhibiting depressivelike behavior showed that chronic stress exposure and administration of antidepressants inhibited and enhanced P-glycoprotein function, respectively [179,181]. A human genetics study (631 MDD, 110 non-depressed controls) revealed a significant association between alteration of the P-glycoprotein encoding gene ATP-binding cassette, subfamily $\mathrm{B}$ member 1 (ABCB1) and MDD $(P=0.034)[180]$.

\section{Theoretical integration with oxidative and neuroinflammatory mechanisms}

\section{Oxidative stress}

Common ROS include superoxide $\left(\mathrm{O}_{2}^{-}\right)$, hydroxyl radical $\left(\mathrm{HO}^{-}\right)$, hydrogen peroxide $\left(\mathrm{H}_{2} \mathrm{O}_{2}^{-}\right)$, and peroxynitrite $\left(\mathrm{ONOO}^{-}\right)$. $\mathrm{ONOO}^{-}$is a highly reactive oxidant generated by the reaction of nitric oxide $(\mathrm{NO})$ with $\mathrm{O}_{2}^{-}[8,15,123]$. The brain is particularly susceptible to oxidative stress due to high levels of peroxidizable polyunsaturated fatty acids and transition minerals (reduced form) that induce lipid peroxidation and convert $\mathrm{H}_{2} \mathrm{O}_{2}^{-}$to $\mathrm{HO}^{-}$; additionally, the brain's oxygen demand is particularly high and the presence of antioxidant defense mechanisms is relatively limited $[8,11,12]$.

Although ROS can limit injury and promote recovery at low levels, ROS facilitate oxidative injury at high levels by damaging biological macromolecules, such as lipids, proteins, and DNA $[8,11,12]$. We hypothesize that oxidative stress associated with MDD may impair neurovascular function through several mechanisms, with an emphasis on mechanisms that can shift the functional balance between beneficial endothelial nitric oxide synthase (eNOS)-generated $\mathrm{NO}$ versus harmful eNOS-generated $\mathrm{O}_{2}^{-}$ (Figure 2 and Table 1).

NO has been termed 'Janus faced' owing to its ability to either protect vascular endothelial cell function in some instances, while impairing it in others [193]. These differential effects of $\mathrm{NO}$ are primarily determined by its cellular source (non-endothelial vs endothelial) and concentration (high vs low). NOS isoforms regulate NO synthesis in the brain. Of these, one is constitutively expressed in endothelial cells and astrocytes (eNOS) $[194,195]$ (that is, eNOS), and another is expressed in neurons (neuronal NOS (nNOS)).

eNOS regulates vascular smooth muscle tone and nNOS modulates neurotransmission. The expression of a third NOS isoform, iNOS, occurs in glial and inflammatory cells and is induced by pathological inflammatory states, such as following trauma [38]. More recently, a fourth NOS isoform was described, mitochondrial (mtNOS), which is an eNOS-like isoform that is constitutively expressed in the inner mitochondrial membrane $[196,197]$. When combined with $\mathrm{O}_{2}^{-}$, NO produced by non-endothelial cellular sources (as regulated by nNOS, iNOS) can impair the vascular endothelium and disrupt BBB integrity $[38,53]$. nNOS activity itself is positively regulated by $\mathrm{Ca}^{2+}$ influx [198], whereas iNOS activity is positively regulated by proinflammatory cytokine [199] and NFKB signaling [200].

NO produced by endothelial cells (as regulated by eNOS) increases cellular levels of cyclic guanosine monophosphate, which can increase cerebral blood flow via mechanisms involving endothelium-dependent vasodilation and platelet aggregation inhibition [38,53,201]. In vitro studies showed that endothelial-derived $\mathrm{NO}$ may dilate cerebral vessels by inhibiting the synthesis of 20-hydroxyeicostetranoic acid-an arachidonic acid metabolite that promotes vasoconstriction [202,203]. Endothelial-derived NO can also limit endothelial vascular oxidative stress injury by scavenging free radicals $[38,53]$. Endothelial eNOS mediates NO synthesis via oxidative conversion of L-arginine to L-citrulline. Activity of eNOS is modulated by several factors, including endothelial levels of $\mathrm{Ca}^{2+}$, arginine (eNOS substrate) [204], as well as tetrahydrobiopterin $\left(\mathrm{BH}_{4}\right)$ (eNOS cofactor) $[53-55,201,205,206]$ (Figure 2). Downregulation of eNOS activity can decrease endothelial NO levels, potentially resulting in (a) reduced cerebral blood flow, (b) increased platelet aggregation, which may contribute to the increased risk of cardiovascular disease in MDD, (c) increased oxidative stress, and (d) decreased vascular reactivity [38,53,201].

Under oxidative conditions, such as those associated with MDD [4,8,11,12,15] (Figure 1), endothelial levels of $\mathrm{BH}_{4}$ are decreased due to increased oxidative conversion of $\mathrm{BH}_{4}$ to dihydrobiopterin $\left(\mathrm{BH}_{2}\right)$. Decreased endothelial levels of $\mathrm{BH}_{4}$ and increased endothelial levels of $\mathrm{BH}_{2}$ (which can also reduce $\mathrm{BH}_{4}$ binding to eNOS) uncouple $\mathrm{L}$-arginine oxidation from the electron transfer process and shift the eNOS substrate from L-arginine to molecular oxygen (that is, eNOS uncoupling), thereby promoting the synthesis of harmful $\mathrm{O}_{2}^{-}$instead of beneficial $\mathrm{NO}$ [53-55,205,207,208]. Once formed, $\mathrm{O}_{2}^{-}$reacts with residual NO (still being produced at a lower rate) to form $\mathrm{ONOO}^{-}$[205]. $\mathrm{ONOO}^{-}$in turn oxidizes $\mathrm{BH}_{4}$, thereby further decreasing its levels in a positive feedback loop [54,205] (Figure 2).

Data from in vitro animal models of neurological disorders show that upregulation of iNOS and nNOS expression and downregulation of eNOS expression can 
worsen neuronal injury [209-213]. In murine models of ischemic stroke, knocking out iNOS and nNOS decreased the size of infarct while knocking out eNOS expanded infracted zone, compared to wild-type mice $[214,215]$. In animal models of traumatic brain injury, increased levels of endothelial $\mathrm{ONOO}^{-}$are associated with BBB breakdown and neurobehavioral deficits [209]; additionally, treatment with the antioxidant $S$-nitrosoglutathione enhances neural reparative mechanisms and improves neurovascular unit function by decreasing endothelial $\mathrm{ONOO}^{-}$synthesis [209].

Clinical and experimental studies suggest that eNOS uncoupling can contribute to vascular endothelial dysfunction in both cardiovascular diseases and MDD $[4,53-55,182,205,206,216]$. In cardiovascular diseases, eNOS uncoupling-mediated endothelial dysfunction is thought to result from (a) increased $\mathrm{O}_{2}^{-}$synthesis (through an $\mathrm{NAD}(\mathrm{P}) \mathrm{H}$ oxidase-dependent mechanism), (b) increased $\mathrm{ONOO}^{-}$formation, and (c) decreased $\mathrm{BH}_{4}$ levels $[54,55,182,206]$. In MDD, however, the potential contribution of eNOS uncoupling to vascular endothelial dysfunction is inferred from less direct evidence. For example, several clinical studies of persons with MDD have shown significant reductions in eNOS activity and NO levels in platelets and sera, respectively [53-57]. In a study of 57 MDD patients

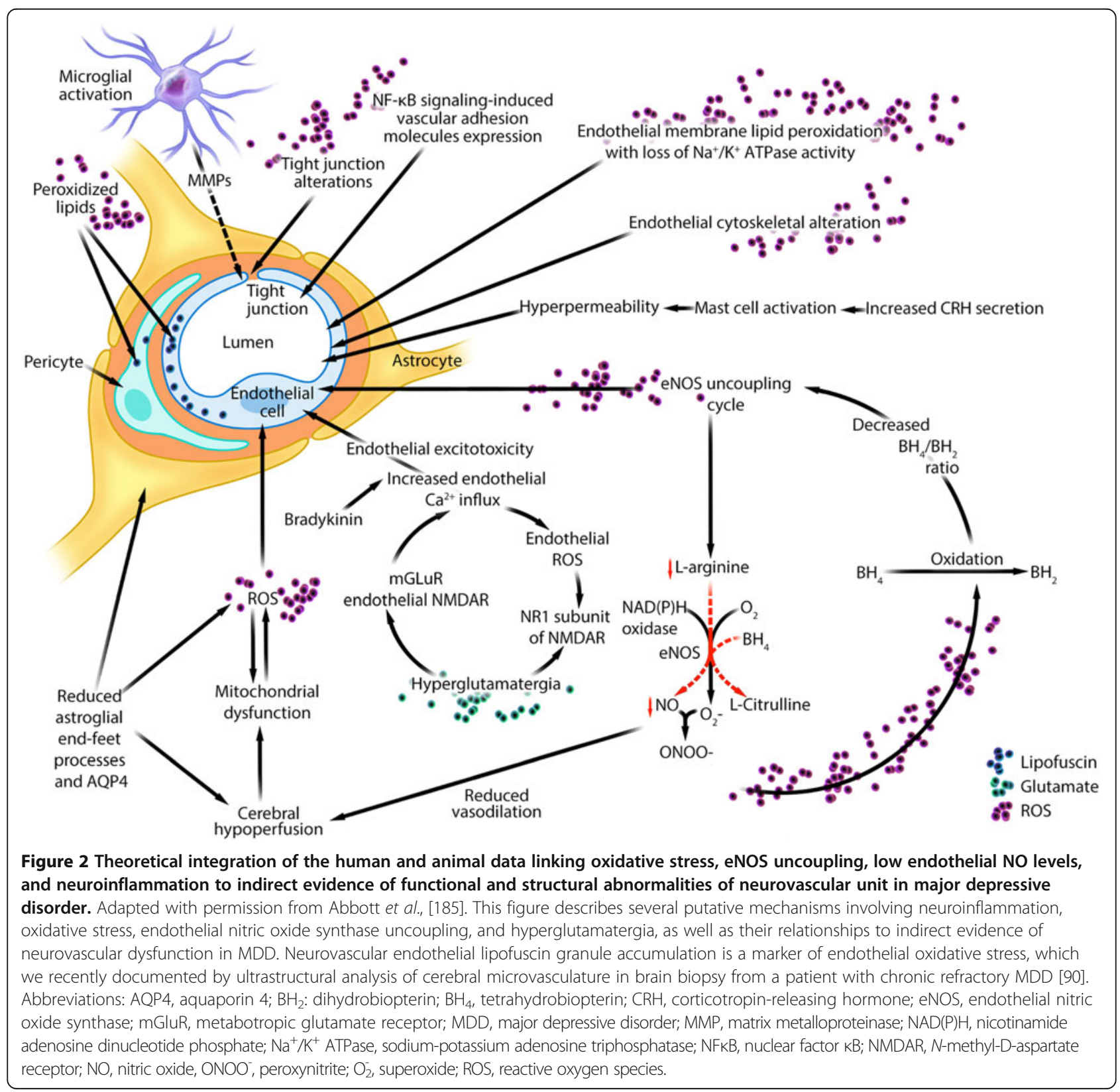


randomized to either citalopram $(n=36)$ or placebo $(n=21)$, a 3-month trial of citalopram was associated with a statistically significant increase in serum NO levels compared to placebo $(P=0.005)$ [58]. Another study involving a 2-month trial of paroxetine reproduced similar results [59]. Fluoxetine treatment in a chronic stress mouse model restored previously deficient aortic endothelial NO levels [60], suggesting that eNOS uncoupling may not only occur in MDD, but also that eNOS recoupling may be one of the mechanisms by which antidepressants exert their therapeutic effects $[8,11,14]$.

The antidepressant effect of L-methylfolate, which can reverse eNOS uncoupling in vitro via upregulating $\mathrm{BH}_{4}$ synthesis [206], suggests that eNOS uncoupling contributes to the neurobiology of MDD. A randomized controlled trial showed that adding L-methylfolate at $15 \mathrm{mg} /$ day, but not at $7.5 \mathrm{mg} /$ day, to a stable regimen of selective serotonin reuptake inhibitors (SSRIs) had superior efficacy to SSRIs plus placebo [217]. Although the authors attributed $\mathrm{BH}_{4}$ augmenting the antidepressant effects of SSRIs to direct activation of the rate-limiting enzymes of monoamine synthesis (serotonin, norepinephrine, dopamine), we suggest that these effects may also be related to the ability of $\mathrm{BH}_{4}$ to reverse eNOS uncoupling.

Although regionally selective (thalamic nuclei, prefrontal, anterior cingulate, temporal, and occipital cortices) cerebral hypoperfusion abnormalities in MDD have traditionally been attributed to depressed mood states and reduced neuronal activity [87-91] [208], these findings may also be related to eNOS uncoupling $[65,113,114,218]$ (Figure 2). Sustained cerebral hypoperfusion can impair endothelial mitochondrial oxidative function, resulting in increased synthesis of endothelial ROS [219-222]. ROS can in turn promote eNOS uncoupling, leading to reduced vasodilatory endothelial NO levels and cerebral hypoperfusion in a positive feedback loop $[54,55,182,206]$. In addition, SSRIs have been shown to induce vasodilation through eNOS-mediated downregulation of NO [223]. We recently reported a case of chronic and refractory MDD with moderately severe bifrontal cerebral hypoperfusion (seen via single photon emission tomography (SPECT)) associated with lipofuscin granule accumulation (a marker of oxidative stress [224-228]) (Figure 2) identified exclusively within the neurovascular unit (predominately within the endothelium) [90]; restoration of cerebral hypoperfusion in temporal association with intravenous immunoglobulin and minocycline therapy was accompanied with significant improvement of depressive symptoms, after more than 20 years of refractoriness to conventional psychiatric treatments [90]. We suggest that eNOS uncoupling may occur in MDD primarily as the result of non- heritable factors such as oxidative mechanisms. Indeed, several genetic studies show a non-significant association between eNOS gene polymorphisms and MDD [229,230].

Under oxidative conditions, BBB endothelial cells are not only the source of harmful eNOS uncoupling, but also can be the target of oxidative damage [39]. In neurological disorders associated with neurovascular dysfunction, oxidative stress can also increase BBB permeability through several mechanisms (Table 1), which include: (a) activation of metalloproteinase (MMP)-2/9 directly or indirectly through proinflammatory cytokines [39]; (b) downregulation of endothelial expression of E-cadherin [38]; (c) alteration of the expression, distribution, and phosphorylation of BBB tight junction proteins (for example, claudin, occluding, ZO proteins) by molecules such as phosphatidylinositol-3-kinase $\gamma[38,41,103,104]$; (d) alteration of endothelial cytoskeletal structure; (e) induction of endothelial NMDAR subunit expression such as NMDA receptor subunit 1 (NR1) subunit, leading endothelial excitotoxicity [40]; and (f) impairment of vascular endothelial mitochondrial oxidative metabolism $[11,123]$. The relevance of these mechanisms to the neurobiology of MDD, however, remains unclear (Table 1 and Figure 2).

\section{Neuroinflammation}

Neuroinflammation may impair neurovascular function and increase BBB permeability in MDD [4,168] (Figure 2 and Table 1). Astroglial cells are an integral part of the neurovascular unit. They are involved in regulating blood flow, BBB permeability, energy metabolism, and neuronal signaling $[4,184]$. Astroglial loss has been consistently documented in functionally relevant areas (prefrontal and cingulate cortices, amygdala, hippocampus) among persons with MDD [4,142,168,231-236]. Other studies have documented decreased expression of the astroglial end-feet process water channel, aquaporin 4 (AQP4) in the orbitofrontal cortical gray matter (but not white matter) of individuals with MDD relative to nondepressed controls [142]. Animal models of depressivelike behavior also found decreased AQP4 density in association with oxidative stress [143]. Decreased AQP4 density may impair critical glial-vascular homeostatic pathways within the neurovascular unit and increase BBB permeability (Figure 2). Reduced AQP4 density may also contribute to cerebral perfusion and metabolic abnormalities detected by SPECT and PET imaging in human MDD [184].

Microglia provide immune surveillance and regulate developmental synaptic pruning of the brain [237]. Although transient microglial activation and proliferation (MAP) can limit neuronal injury and enhance recovery (beneficial phenotype), persistent MAP can induce and exacerbate neuronal injury (harmful phenotype) [238]. Harmful MAP is implicated in the pathophysiology of 
MDD $[4,17,19]$, though neuropathological evidence of MAP in the brains of subjects with MDD is inconsistent $[4,18,148,239]$. One neuropathological study found a positive association between suicidality and both MAP density and microglial quinolinic acid expression [17]. In rats, chronic psychological stress promotes MAP in the prefrontal cortex, amygdala, and hippocampus [19]. Recent meta-analysis in MDD patients confirmed elevation of serum levels of proinflammatory cytokines, such as interleukin 6 (IL-6) and TNF $[23,240]$. Multiple in vitro studies of various neurological conditions showed that MAP and proinflammatory cytokines could increase BBB permeability $[4,38-40,168,184,241]$ (Figures 1 and 2) (Table 1). BBB hyperpermeability may in turn increase crosstalk between innate and adaptive immunity, thereby resulting in further upregulation of MAP and brain cytokine production in a positive feedback loop [242]. MAP can activate iNOS $[8,11,26,27]$, increase ROS synthesis [28], and promote COX2 expression within the neurovascular unit [4]; these factors may increase BBB permeability in vitro $[38,53]$. MAP and proinflammatory cytokines can release and activate matrix metalloproteinases (MMPs) [38,39,168], which have been shown in vitro to disrupt $\mathrm{BBB}$ endothelial tight junction proteins and increase BBB opening $[38,39,168,184]$. Serum MMP-9 levels have been shown to correlate with depressive symptom severity in humans (as assessed by the Hamilton Depression Scale) [97]. Highly reproducible in vitro data showed that proinflammatory cytokines (TNF $\alpha$, IL-1 $\beta$, interferon $\gamma($ IFN $\gamma)$ ) can cause a dosedependent increase in BBB permeability by inducing expression of intercellular adhesion molecule 1 (ICAM-1) on the luminal surface of BBB endothelial cells in animals [243-249] and humans [250,251]. One neuropathological study found a significant increase in the ICAM-1 expression in the deep white matter of the dorsolateral prefrontal cortex in MDD relative to controls [172]. Another study showed SSRIs can reduce vascular endothelial expression and serum levels of both ICAM-1 and vascular cell adhesion molecule 1 (VCAM-1) [173]. Thus, increased BBB endothelial cell expression of adhesion molecules may be one mechanism by which BBB hyperpermeability occurs in MDD [174,252] (Figure 2). However, contrary to this interpretation, a separate postmortem study has shown decreased expression of VCAM-1 and ICAM-1 in the orbitofrontal cortex in depressed subjects compared with non-depressed controls [174]. Increased TNF $\alpha$ production occurring after acute myocardial infarction is associated with an increased risk of MDD and BBB endothelial hyperpermeability [241]. In vitro animal studies showed that TNF $\alpha$ could reduce mitochondrial density and impair mitochondrial oxidative metabolism, leading to increased ROS synthesis [11,253]. Several lines of human
[65,113-121] and animal [65,122] evidence implicate mitochondrial abnormalities in MDD. In vitro data mechanistically link mitochondrial abnormalities to oxidative injury-related vascular abnormalities [219] (Figures 1 and 2). Thus, proinflammatory cytokines may also induce depression and increase BBB permeability by promoting oxidative stress and impairing mitochondrial functions. The relevance of these mechanisms to MDD, however, remains unproven.

Bradykinin is a polypeptide that mediates inflammation, vasodilation, and increased capillary permeability. Human data of bradykinin alterations in MDD are limited to evidence of functional single nucleotide polymorphisms of the bradykinin receptor $\mathrm{B} 2$ gene (BDKRB2) [158] (Table 1). LPS-induced depressive-like behavior in mice was associated with upregulation of bradykinin activity and bradykinin B1 receptor expression [159]; further, selective bradykinin B1 receptor antagonists improved depression-like behavior [159]. Activation of bradykinin and its inducible $\mathrm{B} 1$ and constitutively expressed B2 receptors induces inflammation, promotes oxidative injury, and increases BBB permeability [160] (Figures 1 and 2). Bradykinin activation can augment the astroglial NFKB pathway-mediated IL-6 production, which may increase BBB permeability $[168,184]$. Bradykinin activation can also stimulate phospholipase A2 activity, which in turn enhances arachidonic acid release and its metabolism, leading to increased malondialdehyde [12] and NO production [38] that may increase BBB permeability. Activation of B2 receptor increases endothelial $\mathrm{Ca}^{2+}$ influx, which can activate pro-oxidant enzymes involved in ROS synthesis $[38,168,184]$. Increased ROS production can increase BBB permeability and its susceptibility to the harmful effects of bradykinin [12]. In vitro human studies showed that inflammationrelated upregulation of $\mathrm{BBB}$ endothelial bradykinin $\mathrm{B} 1$ receptor expression could increase BBB permeability [160].

Glutamatergic hyperfunction may contribute to neurovascular dysfunction in MDD (Figure 2 and Table 1). Numerous experimental paradigms such as, brain proton magnetic resonance imaging, postmortem brain investigations, and CSF studies, have documented glutamatergic hyperfunction in persons with MDD $[4,161,162]$. Neuroinflammation may contribute to hyperglutamatergia in a positive feedback loop through several potential mechanisms, which include: (a) inhibition and reversal of astroglial excitatory amino acid transporter-mediated glutamate reuptake function (this process mediates more than $90 \%$ of glutamate uptake [254]); (b) stimulation of microglial synthesis of quinolinic acid, which can promote synaptosomal glutamate release and increase astroglial glutamate and D-serine release; and (c) upregulation of MAP expression of $X_{\mathrm{C}}$ antiporter system, which increases microglial glutamate release [4]. Postmortem investigations of $N$-methyl-D-aspartate 
receptors (NMDARs) subunit expression in the brains of MDD subjects compared with those of non-depressed controls show (a) an increase or no change of NR1 subunit expression in the hippocampus [107-109], (b) an increase of NR2A and NR2B subunit expression in the hippocampus $[107,108]$, (c) a decrease or no change in NR1 subunit expression in the prefrontal cortex $[110,111]$, (d) a decrease of NR2A and NR2B subunit expression in the prefrontal cortex [110], and (e) an increase of NR2A subunit expression in the lateral amygdalae [255]. Binding of excess glutamate to its dysregulated $\mathrm{BBB}$ endothelial ionic NMDARs and metabotropic glutamate receptors (mGluRs) can increase intracellular $\mathrm{Ca}^{2+}$ level-dependent oxidative stress and BBB permeability via increasing $\mathrm{Ca}^{2+}$ influx and release from endoplasmic reticulum stores, respectively $[38,40,159,256]$. Animal data showed that NMDAR activation facilitates free radical production such as $\mathrm{ONOO}^{-}[38,40,256]$ (Figures 1 and 2). Administration of glutamate receptor antagonists has been shown to attenuate NMDAR-induced oxidative stress [40]. Animal studies showed that oxidative stress in turn can alter cerebral endothelial NMDAR subunit composition and upregulate NR1 subunit expression [40], thus setting up a positive feedback loop that increases BBB endothelium vulnerability to both glutamate excitotoxicity and oxidative stress [40]. Alteration of endothelial NMDAR subunit compositions may also reduce cerebral blood flow, as physiologic activation of endothelial NMDAR may activate eNOS and increase endothelial-derived NO [256]. BBB breakdown may also increase CNS glutamate levels via disruption of endothelialbound glutamate efflux transporters [44]; in turn, hyperglutamatergia may heighten BBB susceptibility to the harmful effects of bradykinin. Administration of glutamate receptor antagonists can block bradykinin-induced endothelial $\mathrm{Ca}^{2+}$ rise [38]. Thus, BBB hyperpermeability, increased endothelial NMDAR expression, and increased CNS glutamate levels may contribution to neuronal dysfunction in MDD.

Mast cells are tissue-bound granulated cells most commonly found in the skin and gastrointestinal tract. They, like basophils, contain high levels of histamine and heparin. In the brain, mast cells are particularly abundant in the hypothalamic region. Mast cell activation has been associated with MDD [169] (Table 1). Approximately $40 \%$ to $70 \%$ of persons with mastocytosis, an uncommon and heterogeneous syndrome characterized by increased mast cell density, exhibit depressive symptoms [257]. Increased corticotropin-releasing hormone (CRH) secretion may contribute to mast cell activation associated with MDD [168,170,171]. Experimental evidence suggests that mast cells can cause inflammation [170], modulate BBB permeability [170], and facilitate NMDAR-induced neuronal excitotoxicity [170] (Figure 2). Mast cell activation can release inflammatory substances (for example, IL-6, TNF $\alpha$, vascular endothelial growth factor) and stimulate vascular endothelial cell adhesion molecule expression [170]. These molecules can disrupt BBB integrity and enhance inflammatory cell transmigration into the brain [170].

\section{Future Directions}

Human and animal studies are needed to evaluate the validity of the $\mathrm{BBB}$ dysfunction hypothesis and to explore the mechanistic links between oxidative stress, eNOS uncoupling, and neuroinflammation and neurovascular unit dysfunction with BBB hyperpermeability in MDD. Future postmortem studies investigating the relationship between neurovascular unit dysfunction with BBB hyperpermeability and MDD should focus primarily on the neuroanatomical regions where astroglial loss and MAP have been documented in MDD brains such as anterior mid/cingulate cortex, prefrontal cortex, amygdala, and white matter [4]. Developing methods with increased sensitivity to detect and quantitate subtle BBB hyperpermeability in MDD are likely to be informative [37]. These methods might utilize fluorescent dyes in animal models of depressive-like behavior similar to those developed for in vivo imaging of specific neurovascular elements in animal models of various neurological disorders associated with neurovascular dysfunction [43]: sulforhodamine 101 dye, $\mathrm{Ca}^{2+}$ sensitive dyes, glial fibrillary acidic protein (GFAP), AQP4 (astroglia), CX3C chemokine receptor 1 (CX3CR1) (microglia), dextranconjugated dyes, alpha SMA-RFPcherry (pericytes), dextran dyes, Tie2 (vasculature) and Thy1 (neurons) [43]. A promising neuroimaging modality for visualizing MAP in humans with psychiatric illnesses is PET imaging utilizing microglial peripheral benzodiazepine receptor (also known as translocator protein) C11-PK11195 radioligand $[4,258-260]$. We suspect that various neurovascular processes particularly those promoting endothelial (and potentially astroglial) eNOS dysfunction may emerge as key targets for cellular and molecular research in MDD. Adequately powered randomized controlled trials investigating the effects of anti-inflammatory agents and antioxidants in MDD $[4,90]$ should also assess their effects on cerebral microvascular endothelial functions (for example, by utilizing techniques that measure peripheral vascular dilatory response [182] and cerebral perfusion [90]), as well as the relationship between the extent of endothelial dysfunction and the severity of depressive symptoms.

\section{Conclusions}

Neurovascular dysfunction with BBB hyperpermeability may occur in MDD. Cumulative clinical and experimental evidence implicates oxidative stress, eNOS uncoupling, and reduced endothelial NO levels in the pathophysiology of peripheral vascular endothelial dysfunction associated with 
MDD. Our theoretical integration of the human and animal data links oxidative stress, eNOS uncoupling, low endothelial NO levels, and neuroinflammation to putative neurovascular and BBB abnormalities in MDD. If future studies confirm their relevance to the pathophysiology of MDD, novel agents correcting these abnormalities may prove to be effective treatment strategies.

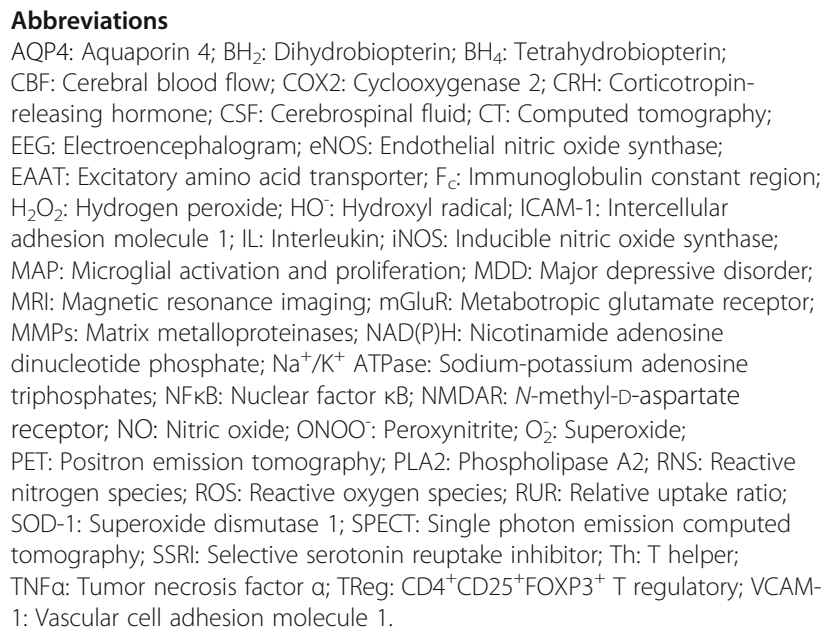

\section{Competing interests}

The authors declare that they have no competing interests.

\section{Authors' contributions}

SN, DMP conceived and designed the research; SN, DMP wrote the manuscript; SN, DMP, AN, OD, DZ, revised the manuscript for important content; SN, DMP, AN, OD, DZ, performed literature searches and gathered data for the review; all authors read and approved the final version of the manuscript for submission.

\section{Author details \\ 'Department of Neurology, Neuroinflammation Research Group, Epilepsy Center Division, NYU School of Medicine, New York, NY 10016, USA. ${ }^{2}$ Department of Neurology, NYU Comprehensive Epilepsy Center, NYU School of Medicine, New York, NY 10016, USA. ${ }^{3}$ The Dartmouth Institute for Health Policy and Clinical Practice, Geisel School of Medicine at Dartmouth, Lebanon, NH 03766, USA. ${ }^{4}$ Department of Pathology, Division of Neuropathology, NYU School of Medicine, New York, NY 10016, USA. ${ }^{5}$ Department of Neurosurgery, NYU School of Medicine, New York, NY 10016, USA.}

Received: 15 August 2013 Accepted: 15 November 2013 Published: 1 December 2013

\section{References}

1. Murray CJ, Vos T, Lozano R, Naghavi M, Flaxman AD, Michaud C, Ezzati M, Shibuya K, Salomon JA, Abdalla S, Aboyans V, Abraham J, Ackerman I, Aggarwal R, Ahn SY, Ali MK, Alvarado M, Anderson HR, Anderson LM, Andrews KG, Atkinson C, Baddour LM, Bahalim AN, Barker-Collo S, Barrero LH, Bartels DH, Basáñez MG, Baxter A, Bell ML, Benjamin EJ, et al: Disabilityadjusted life years (DALYs) for 291 diseases and injuries in 21 regions, 1990-2010: a systematic analysis for the Global Burden of Disease Study 2010. Lancet 2012, 380:2197-2223.

2. Trivedi MH, Rush AJ, Wisniewski SR, Nierenberg AA, Warden D, Ritz L, Norquist G, Howland RH, Lebowitz B, McGrath PJ, Shores-Wilson K, Biggs MM, Balasubramani GK, Fava M: STAR*D Study Team: Evaluation of outcomes with citalopram for depression using measurement-based care in STAR*D: implications for clinical practice. Am J Psychiatry 2006, 163:28-40.

3. Insel TR, Wang PS: The STAR*D trial: revealing the need for better treatments. Psychiatr Serv 2009, 60:1466-1467.
4. Najjar S, Pearlman DM, Alper K, Najjar A, Devinsky O: Neuroinflammation and psychiatric illness. J Neuroinflammation 2013, 10:43.

5. Belmaker RH, Agam G: Major depressive disorder. N Engl J Med 2008, 358:55-68.

6. Papakostas GI, Shelton RC, Kinrys G, Henry ME, Bakow BR, Lipkin SH, Pi B, Thurmond L, Bilello JA: Assessment of a multi-assay, serum-based biological diagnostic test for major depressive disorder: a pilot and replication study. Mol Psychiatry 2013, 18:332-339.

7. Ozcan ME, Gulec M, Ozerol E, Polat R, Akyol O: Antioxidant enzyme activities and oxidative stress in affective disorders. Int Clin Psychopharmacol 2004, 19:89-95.

8. Ng F, Berk M, Dean O, Bush Al: Oxidative stress in psychiatric disorders: evidence base and therapeutic implications. Int I Neuropsychopharmacol 2008, 11:851-876.

9. Berk M, Copolov DL, Dean O, Lu K, Jeavons S, Schapkaitz I, Anderson-Hunt M, Bush Al: N-acetyl cysteine for depressive symptoms in bipolar disorder - A double-blind randomized placebo-controlled trial. Biol Psychiatry 2008, 64:468-475.

10. Maes M, Ruckoanich P, Chang YS, Mahanonda N, Berk M: Multiple aberrations in shared inflammatory and oxidative \& nitrosative stress (IO\&NS) pathways explain the co-association of depression and cardiovascular disorder (CVD), and the increased risk for CVD and due mortality in depressed patients. Prog Neuropsychopharmacol Biol Psychiatry 2011, 35:769-783.

11. Scapagnini G, Davinelli S, Drago F, De Lorenzo A, Oriani G: Antioxidants as antidepressants: fact or fiction? CNS Drugs 2012, 26:477-490.

12. Maes M, Mihaylova I, Kubera M, Leunis JC, Geffard M: IgM-mediated autoimmune responses directed against multiple neoepitopes in depression: new pathways that underpin the inflammatory and neuroprogressive pathophysiology. J Affec Disord 2011, 135:414-418.

13. Galecki P, Szemraj J, Bienkiewicz M, Florkowski A, Galecka E: Lipid peroxidation and antioxidant protection in patients during acute depressive episodes and in remission after fluoxetine treatment. Pharmacol Rep 2009, 61:436-447.

14. Gibson SA, Korade Z, Shelton RC: Oxidative stress and glutathione response in tissue cultures from persons with major depression. J Psychiatr Res 2012, 46:1326-1332.

15. Maes M, Galecki P, Chang YS, Berk M: A review on the oxidative and nitrosative stress (O\&NS) pathways in major depression and their possible contribution to the (neuro)degenerative processes in that illness. Prog Neuropsychopharmacol Biol Psychiatry 2011, 35:676-692.

16. Gawryluk JW, Wang JF, Andreazza AC, Shao L, Young LT: Decreased levels of glutathione, the major brain antioxidant, in post-mortem prefrontal cortex from patients with psychiatric disorders. Int $J$ Neuropsychopharmacol 2011, 14:123-130.

17. Steiner J, Bogerts B, Sarnyai Z, Walter M, Gos T, Bernstein HG, Myint AM: Bridging the gap between the immune and glutamate hypotheses of schizophrenia and major depression: potential role of glial NMDA receptor modulators and impaired blood-brain barrier integrity. World $J$ Biol Psychiatry 2012, 7:482-492.

18. Steiner J, Bielau H, Brisch R, Danos P, Ullrich O, Mawrin C, Bernstein HG, Bogerts B: Immunological aspects in the neurobiology of suicide: elevated microglial density in schizophrenia and depression is associated with suicide. J Psychiatr Res 2008, 42:151-157.

19. Frick $L R$, Williams $K$, Pittenger $C$ : Microglial dysregulation in psychiatric disease. Clin Dev Immunol 2013, 2013:608654.

20. Gosselin RD, Gibney S, O'Malley D, Dinan TG, Cryan JF: Region specific decrease in glial fibrillary acidic protein immunoreactivity in the brain of a rat model of depression. Neuroscience 2009, 159:915-925.

21. Banasr M, Duman RS: Glial loss in the prefrontal cortex is sufficient to induce depressive-like behaviors. Biol Psychiatry 2008, 64:863-870.

22. Haroon $\mathrm{E}$, Raison $\mathrm{CL}$, Miller $\mathrm{AH}$ : Psychoneuroimmunology meets neuropsychopharmacology: translational implications of the impact of inflammation on behavior. Neuropsychopharmacology 2012, 37:137-162.

23. Liu Y, Ho RC, Mak A: Interleukin (IL)-6, tumour necrosis factor alpha (TNFalpha) and soluble interleukin-2 receptors (sIL-2R) are elevated in patients with major depressive disorder: a meta-analysis and meta-regression. $J$ Affect Disord 2012, 139:230-239.

24. Raison CL, Lowry CA, Rook GA: Inflammation, sanitation, and consternation: loss of contact with coevolved, tolerogenic microorganisms and the pathophysiology and treatment of major depression. Arch Gen Psychiatry 2010, 67:1211-1224. 
25. Hong $M$, Zheng J, Ding ZY, Chen JH, Yu L, Niu Y, Hua YQ, Wang LL: Imbalance between Th17 and Treg cells may play an important role in the development of chronic unpredictable mild stress-induced depression in mice. Neuroimmunomodulation 2013, 20:39-50.

26. Anderson G, Berk M, Dodd S, Bechter K, Altamura AC, Dell'osso B, Kanba S, Monji A, Fatemi SH, Buckley P, Debnath M, Das UN, Meyer U, Müller N, Kanchanatawan B, Maes M: Immuno-inflammatory, oxidative and nitrosative stress, and neuroprogressive pathways in the etiology, course and treatment of schizophrenia. Prog Neuropsychopharmacol Biol Psychiatry 2013, 42:1-4.

27. Salim S, Chugh G, Asghar M: Inflammation in anxiety. Adv Protein Chem Struct Biol 2012, 88:1-25.

28. Block ML, Zecca L, Hong JS: Microglia-mediated neurotoxicity: uncovering the molecular mechanisms. Nat Rev Neurosci 2007, 8:57-69.

29. Liu JY, Thom M, Catarino CB, Martinian L, Figarella-Branger D, Bartolomei F, Koepp M, Sisodiya SM: Neuropathology of the blood-brain barrier and pharmaco-resistance in human epilepsy. Brain 2012, 135:3115-3133.

30. Khatri R, McKinney AM, Swenson B, Janardhan V: Blood-brain barrier, reperfusion injury, and hemorrhagic transformation in acute ischemic stroke. Neurology 2012, 79:S52-S57.

31. Cristante E, McArthur S, Mauro C, Maggioli E, Romero IA, Wylezinska-Arridge M, Couraud PO, Lopez-Tremoleda J, Christian HC, Weksler BB, Malaspina A, Solito E: Identification of an essential endogenous regulator of bloodbrain barrier integrity, and its pathological and therapeutic implications. Proc Natl Acad Sci U S A 2013, 110:832-841.

32. Carmeliet P, De Strooper B: Alzheimer's disease: a breach in the bloodbrain barrier. Nature 2012,485:451-452.

33. Abbott NJ, Friedman A: Overview and introduction: the blood-brain barrier in health and disease. Epilepsia 2012, 53(Suppl 6):1-6.

34. Garbuzova-Davis S, Rodrigues MC, Hernandez-Ontiveros DG, Tajiri N, FrisinaDeyo A, Boffeli SM, Abraham JV, Pabon M, Wagner A, Ishikawa H, Shinozuka K, Haller E, Sanberg PR, Kaneko Y, Borlongan CV: Blood-brain barrier alterations provide evidence of subacute diaschisis in an ischemic stroke rat model. PLOS ONE 2013, 8:e63553.

35. Lund H, Krakauer M, Skimminge A, Sellebjerg F, Garde E, Siebner HR, Paulson OB, Hesse D, Hanson LG: Blood-brain barrier permeability of normal appearing white matter in relapsing-remitting multiple sclerosis. PLOS ONE 2013, 8:e56375.

36. Correale J, Villa A: The blood-brain-barrier in multiple sclerosis: functional roles and therapeutic targeting. Autoimmunity 2007, 40:148-160.

37. Friedman A, Kaufer D: Blood-brain barrier breakdown and blood-brain communication in neurological and psychiatric diseases. Cardiovasc Psychiatry Neurol 2011, 2011:431470.

38. Pun PB, Lu J, Moochhala S: Involvement of ROS in BBB dysfunction. Free Radic Res 2009, 43:348-364.

39. Lehner C, Gehwolf R, Tempfer H, Krizbai I, Hennig B, Bauer HC, Bauer H: Oxidative stress and blood-brain barrier dysfunction under particular consideration of matrix metalloproteinases. Antioxid Redox Signal 2011 15:1305-1323.

40. Betzen C, White R, Zehendner CM, Pietrowski E, Bender B, Luhmann HJ, Kuhlmann CR: Oxidative stress upregulates the NMDA receptor on cerebrovascular endothelium. Free Radic Biol Med 2009, 47:1212-1220.

41. Jin R, Song Z, Yu S, Piazza A, Nanda A, Penninger JM, Granger DN, Li G: Phosphatidylinositol-3-kinase gamma plays a central role in bloodbrain barrier dysfunction in acute experimental stroke. Stroke 2011, 42:2033-2044.

42. Wang $Q$, Tang XN, Yenari MA: The inflammatory response in stroke. J Neuroimmunol 2007, 184:53-68.

43. Merlini M, Davalos D, Akassoglou K: In vivo imaging of the neurovascular unit in CNS disease. IntraVital 2012, 1:87-94.

44. Shlosberg D, Benifla M, Kaufer D, Friedman A: Blood-brain barrier breakdown as a therapeutic target in traumatic brain injury. Nat Rev Neurol 2010, 6:393-403.

45. Valkanova $\vee$, Ebmeier KP: Vascular risk factors and depression in later life: a systematic review and meta-analysis. Biol Psychiatry 2013, 73:406-413.

46. Yapislar $\mathrm{H}$, Aydogan S, Ozum U: Biological understanding of the cardiovascular risk associated with major depression and panic disorder is important. Int J Psychiatry Clin Pract 2012, 16:27-32.

47. Le Melledo JM, Mahil N, Baker GB: Nitric oxide: a key player in the relation between cardiovascular disease and major depressive disorder? I Psychiatry Neurosci 2004, 29:414-416.
48. Barth J, Schumacher M, Herrmann-Lingen C: Depression as a risk factor for mortality in patients with coronary heart disease: a meta-analysis. Psychosom Med 2004, 66:802-813.

49. Rugulies R: Depression as a predictor for coronary heart disease. a review and meta-analysis. Am J Prev Med 2002, 23:51-61.

50. Carney RM, Freedland KE, Miller GE, Jaffe AS: Depression as a risk factor for cardiac mortality and morbidity: a review of potential mechanisms. J Psychosom Res 2002, 53:897-902.

51. Van der Kooy K, van Hout H, Marwijk H, Marten H, Stehouwer C, Beekman A: Depression and the risk for cardiovascular diseases: systematic review and meta analysis. Int J Geriatr Psychiatry 2007, 22:613-626.

52. Ford DE, Mead LA, Chang PP, Cooper-Patrick L, Wang NY, Klag MJ: Depression is a risk factor for coronary artery disease in men: the precursors study. Arch Intern Med 1998, 158:1422-1426.

53. Stuehr DJ, Santolini J, Wang ZQ, Wei CC, Adak S: Update on mechanism and catalytic regulation in the NO synthases. J Biol Chem 2004, 279:36167-36170

54. Chen CA, Wang TY, Varadharaj S, Reyes LA, Hemann C, Talukder MA, Chen YR, Druhan LJ, Zweier JL: S-glutathionylation uncouples eNOS and regulates its cellular and vascular function. Nature 2010, 468:1115-1118.

55. Chen W, Druhan $\amalg$, Chen CA, Hemann C, Chen YR, Berka V, Tsai AL, Zweier $J$ : Peroxynitrite induces destruction of the tetrahydrobiopterin and heme in endothelial nitric oxide synthase: transition from reversible to irreversible enzyme inhibition. Biochemistry 2010, 49:3129-3137.

56. Luiking YC, Ten Have GA, Wolfe RR, Deutz NE: Arginine de novo and nitric oxide production in disease states. Am J Physiol Endocrinol Metab 2012, 303:E1177-E1189.

57. Ikenouchi-Sugita A, Yoshimura R, Hori H, Umene-Nakano W, Ueda N, Nakamura J: Effects of antidepressants on plasma metabolites of nitric oxide in major depressive disorder: comparison between milnacipran and paroxetine. Prog Neuropsychopharmacol Biol Psychiatry 2009, 33:1451-1453.

58. van Zyl LT, Lesperance F, Frasure-Smith N, Malinin Al, Atar D, Laliberte MA, Serebruany VL: Platelet and endothelial activity in comorbid major depression and coronary artery disease patients treated with citalopram: the Canadian Cardiac Randomized Evaluation of Antidepressant and Psychotherapy Efficacy Trial (CREATE) biomarker sub-study. J Thromb Thrombolysis 2009, 27:48-56.

59. Lara N, Archer SL, Baker GB, Le Melledo JM: Paroxetine-induced increase in metabolic end products of nitric oxide. J Clin Psychopharmacol 2003, 23:408-412.

60. Isingrini E, Belzung C, Freslon JL, Machet MC, Camus V: Fluoxetine effect on aortic nitric oxide-dependent vasorelaxation in the unpredictable chronic mild stress model of depression in mice. Psychosom Med 2012, 74:63-72

61. Jeynes B, Provias J: Significant negative correlations between capillary expressed eNOS and Alzheimer lesion burden. Neurosci Lett 2009, 463:244-248.

62. Szolnoki Z, Havasi V, Bene J, Komlósi K, Szöke D, Somogyvári F, Kondacs A Szabó M, Fodor L, Bodor A, Gáti I, Wittman I, Melegh B: Endothelial nitric oxide synthase gene interactions and the risk of ischaemic stroke. Acta Neurol Scand 2005, 111:29-33.

63. Chrissobolis S, Miller AA, Drummond GR, Kemp-Harper BK, Sobey CG: Oxidative stress and endothelial dysfunction in cerebrovascular disease. Front Biosci (Landmark Ed) 2011, 16:1733-1745

64. Michel TM, Pulschen D, Thome J: The role of oxidative stress in depressive disorders. Curr Pharm Des 2012, 18:5890-5899.

65. Tobe EH: Mitochondrial dysfunction, oxidative stress, and major depressive disorder. Neuropsychiatr Dis Treat 2013, 9:567-573.

66. Frank MG, Hendricks SE, Bessette D, Johnson DR, Wieseler Frank JL, Burke WJ: Levels of monocyte reactive oxygen species are associated with reduced natural killer cell activity in major depressive disorder. Neuropsychobiology 2001, 44:1-6.

67. Wolkowitz OM, Mellon SH, Epel ES, Lin J, Dhabhar FS, Su Y, Reus VI, Rosser R, Burke HM, Kupferman E, Compagnone M, Nelson JC, Blackburn EH: Leukocyte telomere length in major depression: correlations with chronicity, inflammation and oxidative stress - preliminary findings. PLOS ONE 2011, 6:e17837.

68. Szuster-Ciesielska A, Slotwinska M, Stachura A, Marmurowska-Michalowska H, Dubas-Slemp H, Bojarska-Junak A, Kandefer-Szerszen M: Accelerated apoptosis of blood leukocytes and oxidative stress in blood of patients with major depression. Prog Neuropsychopharmacol Biol Psychiatry 2008, 32:686-694. 
69. Shungu DC, Weidschat N, Mao X, Pillemer S, Murrough JW, Mathew SJ: In vivo neuroimaging evidence of oxidative stress in major depressive disorder. Eur Psychiatry 2012, 27:1.

70. Shelton RC, Gibson SA, Korade Z: Elevation of oxidative stress in tissue cultures from persons with major depression. Neuropsychopharmacology 2011, 36:S443-S444.

71. Selek S, Dalkilic A, Kaya MC, Savas HA, Bez Y, Celik H, Erel O, Kaptanoglu B, Herken $\mathrm{H}$ : The relationship of oxidative metabolism to treatment response in major depression: a biological basis for treatment duration. Neurol Psychiatry Brain Res 2012, 18:15-18.

72. Sarandol A, Sarandol E, Eker SS, Erdinc S, Vatansever E, Kirli S: Major depressive disorder is accompanied with oxidative stress: short-term antidepressant treatment does not alter oxidative - Antioxidative systems. Hum Psychopharmacol 2007, 22:67-73.

73. Rawdin BJ, Mellon SH, Dhabhar FS, Epel ES, Puterman E, Su Y, Burke HM, Reus VI, Rosser R, Hamilton SP, Nelson JC, Wolkowitz OM: Dysregulated relationship of inflammation and oxidative stress in major depression. Brain Behav Immun 2013, 31:143-152.

74. Rawdin B, Mellon S, Dhabhar F, Epel E, Su Y, Rosser R, Burke H, Reus V, Hamilton S, Nelson C, Wolkowitz O: Inflammatory and oxidative stress are highly correlated in unmedicated major depression. Brain Behav Immun 2012, 26:\$47.

75. Pasco JA, Nicholson GC, Ng F, Henry MJ, Williams LJ, Kotowicz MA, Hodge JM, Dodd S, Kapczinski F, Gama CS, Berk M: Oxidative stress may be a common mechanism linking major depression and osteoporosis. Acta Neuropsychiatrica 2008, 20:112-116.

76. Nunes SOV, Vargas HO, Prado E, Barbosa DS, de Melo LP, Moylan S, Dodd S, Berk $M$ : The shared role of oxidative stress and inflammation in major depressive disorder and nicotine dependence. Neurosci Biobehav Rev 2013, 37:1336-1345.

77. Mathew S, Murrough J, Mao X, Pillemer S, Shungu D: Proton magnetic resonance spectroscopy measurement of brain glutathione supports increased oxidative stress in major depressive disorder. Neuropsychopharmacology 2010, 35:S151.

78. Maes M, Mihaylova I, Kubera M, Uytterhoeven M, Vrydags N, Bosmans E: Increased 8-hydroxy-deoxyguanosine, a marker of oxidative damage to DNA, in major depression and myalgic encephalomyelitis/chronic fatigue syndrome. Neuroendocrinol Lett 2009, 30:715-722.

79. Leonard B, Maes M: Mechanistic explanations how cell-mediated immune activation, inflammation and oxidative and nitrosative stress pathways and their sequels and concomitants play a role in the pathophysiology of unipolar depression. Neurosci Biobehav Rev 2012, 36:764-785.

80. Kotan VO, Sarandol E, Kirhan E, Ozkaya G, Kirli S: Effects of long-term antidepressant treatment on oxidative status in major depressive disorder: a 24-week follow-up study. Prog Neuropsychopharmacol Biol Psychiatry 2011, 35:1284-1290.

81. Khanzode SD, Dakhale GN, Khanzode SS, Saoji A, Palasodkar R: Oxidative damage and major depression: the potential antioxidant action of selective serotonin-re-uptake inhibitors. Redox Rep 2003, 8:365-370.

82. Herken H, Gurel A, Selek S, Armutcu F, Ozen ME, Bulut M, Kap O, Yumru M Savas HA, Akyol O: Adenosine deaminase, nitric oxide, superoxide dismutase, and xanthine oxidase in patients with major depression: impact of antidepressant treatment. Arch Med Res 2007, 38:247-252.

83. Ghodake SR, Suryakar AN, Kulhalli PM, Padalkar RK, Shaikh AK: A study of oxidative stress and influence of antioxidant vitamins supplementation in patients with major depression. Curr Neurobiol 2012, 3:107-111.

84. Stefanescu $C$, Ciobica A: The relevance of oxidative stress status in first episode and recurrent depression. J Affect Disord 2012, 143:34-38.

85. Zafir A, Ara A, Banu N: Invivo antioxidant status: a putative target of antidepressant action. Prog Neuropsychopharmacol Biol Psychiatry 2009, 33:220-228.

86. Brea D, Roquer J, Serena J, Segura T, Castillo J, Artico S: Oxidative stress markers are associated to vascular recurrence in non-cardioembolic stroke patients non-treated with statins. BMC Neurol 2012, 12:65.

87. Orosz A, Jann K, Federspiel A, Horn H, Hofle O, Dierks T, Wiest R, Strik W, Muller T, Walther S: Reduced cerebral blood flow within the default-mode network and within total gray matter in major depression. Brain Connect 2012, 2:303-310.

88. Smith DJ, Cavanagh JT: The use of single photon emission computed tomography in depressive disorders. Nucl Med Commun 2005, 26:197-203.
89. Vlassenko A, Sheline YI, Fischer K, Mintun MA: Cerebral perfusion response to successful treatment of depression with different serotoninergic agents. J Neuropsychiatry Clin Neurosci 2004, 16:360-363.

90. Najjar S, Pearlman D, Hirsch S, Friedman K, Strange J, Reidy J, Khoukaz M, Ferrell R, Devinsky O, Najjar A, Zagzag D: Brain biopsy findings link major depressive disorder to neuroinflammation, oxidative stress, and neurovascular dysfunction: a case report. Biol Psychiatry 2013. doi: 10.1016/j.biopsych.2013.07.041. [Epub ahead of print]

91. Nagafusa Y, Okamoto N, Sakamoto K, Yamashita F, Kawaguchi A, Higuchi T, Matsuda $\mathrm{H}$ : Assessment of cerebral blood flow findings using $99 \mathrm{mTc}-\mathrm{ECD}$ single-photon emission computed tomography in patients diagnosed with major depressive disorder. J Affect Disord 2012, 140:296-299.

92. Johnson NA, Jahng GH, Weiner MW, Miller BL, Chui HC, Jagust WJ, Gorno-Tempini ML, Schuff N: Pattern of cerebral hypoperfusion in Alzheimer disease and mild cognitive impairment measured with arterial spin-labeling MR imaging: initial experience. Radiology 2005, 234:851-859.

93. Ruitenberg A, den Heijer T, Bakker SL, van Swieten JC, Koudstaal PJ, Hofman A, Breteler MM: Cerebral hypoperfusion and clinical onset of dementia: the Rotterdam Study. Ann Neurol 2005, 57:789-794.

94. de la Torre JC: Critically attained threshold of cerebral hypoperfusion: the CATCH hypothesis of Alzheimer's pathogenesis. Neurobiol Aging 2000, 21:331-342.

95. Waldemar G, Bruhn P, Kristensen M, Johnsen A, Paulson OB, Lassen NA: Heterogeneity of neocortical cerebral blood flow deficits in dementia of the Alzheimer type: a [99mTc]-d, I-HMPAO SPECT study. J Neurol Neurosurg Psychiatry 1994, 57:285-295.

96. Catafau AM: Brain SPECT in clinical practice. Part l: perfusion. I Nucl Med 2001, 42:259-271.

97. Yoshida T, Ishikawa M, Niitsu T, Nakazato M, Watanabe H, Shiraishi T, Shiina A, Hashimoto T, Kanahara N, Hasegawa T, Enohara M, Kimura A, lyo M, Hashimoto K: Decreased serum levels of mature brain-derived neurotrophic factor (BDNF), but not its precursor proBDNF, in patients with major depressive disorder. PLOS ONE 2012, 7:e42676.

98. Grammas P: Neurovascular dysfunction, inflammation and endothelial activation: implications for the pathogenesis of Alzheimer's disease. J Neuroinflammation 2011, 8:26.

99. Kurzepa J, Bielewicz J, Grabarska A, Stelmasiak Z, Stryjecka-Zimmer M, BartosikPsujek H: Matrix metalloproteinase-9 contributes to the increase of tau protein in serum during acute ischemic stroke. J Clin Neurosci 2010, 17:997-999.

100. Manso H, Krug T, Sobral J, Albergaria I, Gaspar G, Ferro JM, Oliveira SA, Vicente AM: Variants of the Matrix Metalloproteinase-2 but not the Matrix Metalloproteinase- 9 genes significantly influence functional outcome after stroke. BMC Med Genet 2010, 11:40.

101. Ramos-Fernandez M, Bellolio MF, Stead LG: Matrix metalloproteinase-9 as a marker for acute ischemic stroke: a systematic review. J Stroke Cerebrovasc Dis 2011, 20:47-54.

102. Agiostratidou G, Muros RM, Shioi J, Marambaud P, Robakis NK: The cytoplasmic sequence of E-cadherin promotes non-amyloidogenic degradation of A beta precursors. J Neurochem 2006, 96:1182-1188.

103. Haorah J, Knipe B, Leibhart J, Ghorpade A, Persidsky Y: Alcohol-induced oxidative stress in brain endothelial cells causes blood-brain barrier dysfunction. J Leukoc Biol 2005, 78:1223-1232.

104. Lochhead JJ, McCaffrey G, Quigley CE, Finch J, DeMarco KM, Nametz N, Davis TP: Oxidative stress increases blood-brain barrier permeability and induces alterations in occludin during hypoxia-reoxygenation. J Cereb Blood Flow Metab 2010, 30:1625-1636.

105. Matsuzaki M, Takahashi R, Nakayama T, Shishikura K, Suzuki H, Hirayama Y, Osawa M, Oda H: Disruption of endothelial tight junctions in a patient with mitochondrial encephalomyopathy, lactic acidosis and stroke-like episodes (MELAS). Neuropediatrics 2010, 41:72-74.

106. Kirk J, Plumb J, Mirakhur M, McQuaid S: Tight junctional abnormality in multiple sclerosis white matter affects all calibres of vessel and is associated with blood-brain barrier leakage and active demyelination. J Pathol 2003, 201:319-327.

107. Oh DH, Park SC, Park YC, Kim SH: Excessive activation of the loop between the NR2B subunit of the N-methyl-D-aspartate receptor and glycogen synthase kinase-3beta in the hippocampi of patients with major depressive disorder. Acta Neuropsychiatrica 2012, 24:26-33.

108. Oh D, Kim SH, Park YC: The biological pathway underlying dysregulation of hippocampal 5HT1A-NR2BGSK-3beta function in major depression. Eur Neuropsychopharmacol 2010, 20:S356. 
109. Toro C, Deakin JF: NMDA receptor subunit NRI and postsynaptic protein PSD-95 in hippocampus and orbitofrontal cortex in schizophrenia and mood disorder. Schizophr Res 2005, 80:323-330.

110. Feyissa AM, Chandran A, Stockmeier CA, Karolewicz B: Reduced levels of NR2A and NR2B subunits of NMDA receptor and PSD-95 in the prefrontal cortex in major depression. Prog Neuropsychopharmacol Biol Psychiatry 2009, 33:70-75.

111. Beneyto M, Meador-Woodruff JH: Lamina-specific abnormalities of NMDA receptor-associated postsynaptic protein transcripts in the prefrontal cortex in schizophrenia and bipolar disorder. Neuropsychopharmacology 2008, 33:2175-2186.

112. Neuhaus W, Freidl M, Szkokan P, Berger M, Wirth M, Winkler J, Gabor F, Pifl C, Noe CR: Effects of NMDA receptor modulators on a blood-brain barrier in vitro model. Brain Res 2011, 1394:49-61.

113. Moreno J, Gaspar E, Lopez-Bello G, Juarez E, Alcazar-Leyva S, GonzalezTrujano E, Pavon L, Alvarado-Vasquez N: Increase in nitric oxide levels and mitochondrial membrane potential in platelets of untreated patients with major depression. Psychiatry Res 2013, 209:447-452.

114. Gardner A, Pagani M, Wibom R, Nennesmo I, Jacobsson H, Hallstom T: Alterations of rCBF and mitochondrial dysfunction in major depressive disorder: a case report. Acta Psychiatr Scand 2003, 107:233-238.

115. Rollins B, Martin MV, Sequeira PA, Moon EA, Morgan LZ, Watson SJ, Schatzberg A, Akil H, Myers RM, Jones EG, Wallace DC, Bunney WE, Vawter MP: Mitochondrial variants in schizophrenia, bipolar disorder, and major depressive disorder. PLOS ONE 2009, 4:e4913.

116. McPhie DL, Logan D, Sargent L, Berry JT, Ravichandran C, Carpenter A, Cohen B: Detecting disease-specific differences in mitochondrial morphology and distribution in fibroblasts from patients with bipolar, schizophrenic, and major depressive disorders. Neuropsychopharmacology 2012, 38:S287.

117. Koene S, Kozicz TL, Rodenburg RJT, Verhaak CM, de Vries MC, Wortmann S, van de Heuvel L, Smeitink JAM, Morava E: Major depression in adolescent children consecutively diagnosed with mitochondrial disorder. J Affect Disord 2009, 114:327-332.

118. Gardner A, Johansson A, Wibom R, Nennesmo I, Von Dobeln U, Hagenfeldt $L$, Hallstrom T: Alterations of mitochondrial function and correlations with personality traits in selected major depressive disorder patients. J Affect Disord 2003, 76:55-68.

119. Gardner A, Boles RG: Beyond the serotonin hypothesis: mitochondria, inflammation and neurodegeneration in major depression and affective spectrum disorders. Prog Neuropsychopharmacol Biol Psychiatry 2011, 35:730-743.

120. Ben-Shachar D, Karry R: Neuroanatomical pattern of mitochondrial complex I pathology varies between schizophrenia, bipolar disorder and major depression. PLOS ONE 2008, 3:e3676.

121. Abdallah CG, Mason GF, De Feyter H, Fasula M, Kelmendi B, Simen A, Jiang L, Krystal JH, Rothman DL, Sanacora G: Reduced mitochondrial energy production in major depressive disorder: associations with the serotonin transporter and glutamine synthetase genes. Neuropsychopharmacology 2012, 38:S127-S128.

122. Della FP, Abelaira HM, Réus GZ, Antunes AR, Dos Santos MA, Zappelinni G, Steckert AV, Vuolo F, Galant LS, Dal-Pizzol F, Kapczinski F, Quevedo J: Tianeptine exerts neuroprotective effects in the brain tissue of rats exposed to the chronic stress model. Pharmacol Biochem Behav 2012, 103:395-402.

123. Enciu AM, Gherghiceanu M, Popescu BO: Triggers and effectors of oxidative stress at blood-brain barrier level: relevance for brain ageing and neurodegeneration. Oxid Med Cell Longev 2013, 2013:297512.

124. Kimura A, Sakurai T, Yamada M, Koumura A, Hayashi Y, Tanaka Y, Hozumi I, Ohtaki H, Chousa M, Takemura M, Seishima M, Inuzuka T: Antibodies against the tom 40 subunit of the translocase of the outer mitochondrial membrane complex and cognitive impairment in Alzheimer's disease. J Alzheimers Dis 2012, 29:373-377.

125. Mecocci P, MacGarvey U, Beal MF: Oxidative damage to mitochondrial DNA is increased in Alzheimer's disease. Ann Neurol 1994, 36:747-751.

126. Miguel-Hidalgo JJ, Baucom C, Dilley G, Overholser JC, Meltzer HY, Stockmeier CA, Rajkowska G: Glial fibrillary acidic protein immunoreactivity in the prefrontal cortex distinguishes younger from older adults in major depressive disorder. Biol Psychiatry 2000, 48:861-873.

127. Altshuler LL, Abulseoud OA, Foland Ross L, Bartzokis G, Chang S, Mintz J, Hellemann G, Vinters HV: Amygdala astrocyte reduction in subjects with major depressive disorder but not bipolar disorder. Bipolar Disord 2010, 12:541-549.
128. Webster MJ, Knable MB, Johnston-Wilson N, Nagata K, Inagaki M, Yolken RH: Immunohistochemical localization of phosphorylated glial fibrillary acidic protein in the prefrontal cortex and hippocampus from patients with schizophrenia, bipolar disorder, and depression. Brain Behav Immun 2001, 15:388-400

129. Doyle C, Deakin JFW: Fewer astrocytes in frontal cortex in schizophrenia, depression and bipolar disorder. Schizophr Res 2002, 53:106.

130. Johnston-Wilson NL, Sims CD, Hofmann JP, Anderson L, Shore AD, Torrey $\mathrm{EF}$, Yolken $\mathrm{RH}$ : Disease-specific alterations in frontal cortex brain proteins in schizophrenia, bipolar disorder, and major depressive disorder. The Stanley Neuropathology Consortium. Mol Psychiatry 2000, 5:142-149.

131. Tseng PT, Lee Y, Lin PY: Age-associated decrease in serum glial cell line-derived neurotrophic factor levels in patients with major depressive disorder. Prog Neuropsychopharmacol Biol Psychiatry 2013, 40:334-339.

132. Ordway GA, Szebeni A, Chandley MJ, Stockmeier CA, Xiang L, Newton SS, Turecki G, Duffourc MM, Zhu MY, Zhu H, Szebeni K: Low gene expression of bone morphogenetic protein 7 in brainstem astrocytes in major depression. Int J Neuropsychopharmacol 2012, 15:855-868.

133. Diniz BS, Teixeira AL, Miranda AS, Talib LL, Gattaz WF, Forlenza OV Circulating Glial-derived neurotrophic factor is reduced in late-life depression. J Psychiatr Res 2012, 46:135-139.

134. Li B, Dong L, Wang B, Cai L, Jiang N, Peng L: Cell type-specific gene expression and editing responses to chronic fluoxetine treatment in the in vivo mouse brain and their relevance for stress-induced anhedonia. Neurochem Res 2012, 37:2480-2495

135. Araya-Callis C, Hiemke C, Abumaria N, Flugge G: Chronic psychosocial stress and citalopram modulate the expression of the glial proteins GFAP and NDRG2 in the hippocampus. Psychopharmacology (Berl) 2012, 224:209-222.

136. Sun JD, Liu Y, Yuan YH, Li J, Chen NH: Gap junction dysfunction in the prefrontal cortex induces depressive-like behaviors in rats. Neuropsychopharmacology 2012, 37:1305-1320.

137. Allaman I, Fiumelli H, Magistretti PJ, Martin JL: Fluoxetine regulates the expression of neurotrophic/growth factors and glucose metabolism in astrocytes. Psychopharmacology (Berl) 2011, 216:75-84.

138. Ye $Y$, Wang $G$, Wang $H$, Wang $X$ : Brain-derived neurotrophic factor (BDNF) infusion restored astrocytic plasticity in the hippocampus of a rat model of depression. Neurosci Lett 2011, 503:15-19.

139. Hayakawa K, Pham LD, Katusic ZS, Arai K, Lo EH: Astrocytic high-mobility group box 1 promotes endothelial progenitor cell-mediated neurovascular remodeling during stroke recovery. Proc Natl Acad Sci USA 2012, 109:7505-7510.

140. Heinemann U, Kaufer D, Friedman A: Blood-brain barrier dysfunction, TGFbeta signaling, and astrocyte dysfunction in epilepsy. Glia 2012, 60:1251-1257.

141. Merlini M, Meyer EP, Ulmann-Schuler A, Nitsch RM: Vascular beta-amyloid and early astrocyte alterations impair cerebrovascular function and cerebral metabolism in transgenic arcAbeta mice. Acta Neuropatho/ 2011, 122:293-311.

142. Rajkowska G, Hughes J, Stockmeier CA, Javier Miguel-Hidalgo J, Maciag D: Coverage of blood vessels by astrocytic endfeet is reduced in major depressive disorder. Biol Psychiatry 2013, 73:613-621.

143. Liu L, Lu Y, Kong H, Li L, Marshall C, Xiao M, Ding J, Gao J, Hu G: Aquaporin-4 deficiency exacerbates brain oxidative damage and memory deficits induced by long-term ovarian hormone deprivation and D-galactose injection. Int J Neuropsychopharmacol 2012, 1:55-68.

144. Takahashi T, Fujihara K, Nakashima I, Misu T, Miyazawa I, Nakamura M, Watanabe S, Ishii N, Itoyama Y: Establishment of a new sensitive assay for anti-human aquaporin-4 antibody in neuromyelitis optica. Tohoku J Exp Med 2006, 210:307-313.

145. Takahashi T, Fujihara K, Nakashima I, Misu T, Miyazawa I, Nakamura M, Watanabe S, Shiga Y, Kanaoka C, Fujimori J, Sato S, Itoyama Y: Antiaquaporin-4 antibody is involved in the pathogenesis of NMO: a study on antibody titre. Brain 2007, 130:1235-1243.

146. Tanaka K, Tani T, Tanaka M, Saida T, Idezuka J, Yamazaki M, Tsujita M, Nakada T, Sakimura K, Nishizawa M: Anti-aquaporin 4 antibody in selected Japanese multiple sclerosis patients with long spinal cord lesions. Mult Scler 2007, 13:850-855.

147. Müller N, Schwarz MJ: The immune-mediated alteration of serotonin and glutamate: towards an integrated view of depression. Mol Psychiatry 2007, 12:988-1000 
148. Steiner J, Walter M, Gos T, Guillemin GJ, Bernstein HG, Sarnyai Z, Mawrin C, Brisch R, Bielau H, Meyer zu Schwabedissen L, Bogerts B, Myint AM: Severe depression is associated with increased microglial quinolinic acid in subregions of the anterior cingulate gyrus: evidence for an immunemodulated glutamatergic neurotransmission? J Neuroinflammation 2011, 8:94.

149. Fenn AM, Henry CJ, Huang Y, Dugan A, Godbout JP: Lipopolysaccharideinduced interleukin (IL)-4 receptor-alpha expression and corresponding sensitivity to the M2 promoting effects of IL-4 are impaired in microglia of aged mice. Brain Behav Immun 2012, 26:766-777.

150. Henry CJ, Huang Y, Wynne AM, Godbout JP: Peripheral lipopolysaccharide (LPS) challenge promotes microglial hyperactivity in aged mice that is associated with exaggerated induction of both pro-inflammatory IL1 beta and anti-inflammatory IL-10 cytokines. Brain Behav Immun 2009, 23:309-317.

151. Wang Y, Lawson MA, Dantzer R, Kelley KW: LPS-induced indoleamine 2,3dioxygenase is regulated in an interferon-gamma-independent manner by a JNK signaling pathway in primary murine microglia. Brain Behav Immun 2010, 24:201-209.

152. Zhang F, Zhou H, Wilson BC, Shi JS, Hong JS, Gao HM: Fluoxetine protects neurons against microglial activation-mediated neurotoxicity. Parkinsonism Relat Disord 2012, 18(Suppl 1):S213-S217.

153. Najjar S, Pearlman D, Miller DC, Devinsky O: Refractory epilepsy associated with microglial activation. Neurologist 2011, 17:249-254.

154. Devinsky O, Vezzani A, Najjar S, De Lanerolle NC, Rogawski MA: Glia and epilepsy: excitability and inflammation. Trends Neurosci 2013, 36:174-184

155. Janelidze S, Mattei D, Westrin A, Traskman-Bendz L, Brundin L: Cytokine levels in the blood may distinguish suicide attempters from depressed patients. Brain Behav Immun 2011, 25:335-339.

156. Dantzer R, O'Connor JC, Freund GG, Johnson RW, Kelley KW: From inflammation to sickness and depression: when the immune system subjugates the brain. Nat Rev Neurosci 2008, 9:46-56.

157. O'Connor JC, Lawson MA, Andre C, Moreau M, Lestage J, Castanon N, Kelley KW, Dantzer R: Lipopolysaccharide-induced depressive-like behavior is mediated by indoleamine 2,3-dioxygenase activation in mice. Mol Psychiatry 2009, 14:511-522.

158. Gratacòs M, Costas J, de Cid R, Bayés M, González JR, Baca-García E, de Diego Y, Fernández-Aranda F, Fernández-Piqueras J, Guitart M, Martín-Santos R, Martorell L, Menchón JM, Roca M, Sáiz-Ruiz J, Sanjuán J, Torrens M, Urretavizcaya M, Valero J, Vilella E, Estivill X, Carracedo A, Psychiatric Genetics Network Group: Identification of new putative susceptibility genes for several psychiatric disorders by association analysis of regulatory and non-synonymous SNPs of 306 genes involved in neurotransmission and neurodevelopment. Am J Med Genet Neuropsychiatr Genet 2009, 150:808-816.

159. Viana AF, Maciel IS, Dornelles FN, Figueiredo CP, Siqueira JM, Campos MM, Calixto JB: Kinin B1 receptors mediate depression-like behavior response in stressed mice treated with systemic E. coli lipopolysaccharide. J Neuroinflammation 2010, 7:98.

160. Prat A, Biernacki K, Pouly S, Nalbantoglu J, Couture R, Antel JP: Kinin B1 receptor expression and function on human brain endothelial cells. J Neuropathol Exp Neurol 2000, 59:896-906.

161. Hashimoto K: Emerging role of glutamate in the pathophysiology of major depressive disorder. Brain Res Rev 2009, 61:105-123.

162. Hashimoto K, Sawa A, lyo M: Increased levels of glutamate in brains from patients with mood disorders. Biol Psychiatry 2007, 62:1310-1316.

163. Sanacora G, Gueorguieva R, Epperson CN, Wu YT, Appel M, Rothman DL, Krystal JH, Mason GF: Subtype-specific alterations of gammaaminobutyric acid and glutamate in patients with major depression. Arch Gen Psychiatry 2004, 61:705-713.

164. John CS, Smith KL, Van't Veer A, Gompf HS, Carlezon WA Jr, Cohen BM, Ongur D, Bechtholt-Gompf AJ: Blockade of astrocytic glutamate uptake in the prefrontal cortex induces anhedonia. Neuropsychopharmacology 2012, 37:2467-2475

165. Cendes F, Andermann F, Carpenter S, Zatorre RJ, Cashman NR: Temporal lobe epilepsy caused by domoic acid intoxication: evidence for glutamate receptor-mediated excitotoxicity in humans. Ann Neurol 1995, 37:123-126

166. Eid T, Thomas MJ, Spencer DD, Runden-Pran E, Lai JC, Malthankar GV, Kim $\mathrm{JH}$, Danbolt NC, Ottersen OP, de Lanerolle NC: Loss of glutamine synthetase in the human epileptogenic hippocampus: possible mechanism for raised extracellular glutamate in mesial temporal lobe epilepsy. Lancet 2004, 363:28-37.

167. Mathern GW, Mendoza D, Lozada A, Pretorius JK, Dehnes Y, Danbolt NC, Nelson N, Leite JP, Chimelli L, Born DE, Sakamoto AC, Assirati JA, Fried I, Peacock WJ, Ojemann GA, Adelson PD: Hippocampal GABA and glutamate transporter immunoreactivity in patients with temporal lobe epilepsy. Neurology 1999, 52:453-472.

168. Shalev $H$, Serlin $Y$, Friedman A: Breaching the blood-brain barrier as a gate to psychiatric disorder. Cardiovasc Psychiatry Neurol 2009, 2009:278531.

169. Piche T, Saint-Paul MC, Dainese R, Marine-Barjoan E, lannelli A, Montoya ML, Peyron JF, Czerucka D, Cherikh F, Filippi J, Tran A, Hébuterne X: Mast cells and cellularity of the colonic mucosa correlated with fatigue and depression in irritable bowel syndrome. Gut 2008, 57:468-473.

170. Theoharides TC, Zhang B: Neuro-inflammation, blood-brain barrier, seizures and autism. J Neuroinflammation 2011, 8:168.

171. Theoharides TC, Konstantinidou AD: Corticotropin-releasing hormone and the blood-brain-barrier. Front Biosci 2007, 12:1615-1628.

172. Thomas AJ, Perry R, Kalaria RN, Oakley A, McMeekin W, O'Brien JT: Neuropathological evidence for ischemia in the white matter of the dorsolateral prefrontal cortex in late-life depression. Int I Geriatr Psychiatry 2003, 18:7-13

173. Lekakis J, Ikonomidis I, Papoutsi Z, Moutsatsou P, Nikolaou M, Parissis J, Kremastinos DT: Selective serotonin re-uptake inhibitors decrease the cytokine-induced endothelial adhesion molecule expression, the endothelial adhesiveness to monocytes and the circulating levels of vascular adhesion molecules. Int J Cardiol 2010, 139:150-158.

174. Miguel-Hidalgo JJ, Overholser JC, Jurjus GJ, Meltzer HY, Dieter L, Konick L, Stockmeier CA, Rajkowska G: Vascular and extravascular immunoreactivity for intercellular adhesion molecule 1 in the orbitofrontal cortex of subjects with major depression: age-dependent changes. $J$ Affect Disord 2011, 132:422-431.

175. Davies MJ, Gordon JL, Gearing AJ, Pigott R, Woolf N, Katz D, Kyriakopoulos A: The expression of the adhesion molecules ICAM-1, VCAM-1, PECAM, and E-selectin in human atherosclerosis. J Pathol 1993, 171:223-229.

176. Hwang SJ, Ballantyne CM, Sharrett AR, Smith LC, Davis CE, Gotto AM Jr, Boerwinkle E: Circulating adhesion molecules VCAM-1, ICAM-1, and E-selectin in carotid atherosclerosis and incident coronary heart disease cases: the Atherosclerosis Risk In Communities (ARIC) study. Circulation 1997, 96:4219-4225.

177. Kim I, Moon SO, Kim SH, Kim HJ, Koh YS, Koh GY: Vascular endothelial growth factor expression of intercellular adhesion molecule 1 (ICAM-1), vascular cell adhesion molecule 1 (VCAM-1), and E-selectin through nuclear factor-kappa B activation in endothelial cells. J Biol Chem 2001, 276:7614-7620

178. Hartung HP, Michels M, Reiners K, Seeldrayers P, Archelos JJ, Toyka KV: Soluble ICAM-1 serum levels in multiple sclerosis and viral encephalitis. Neurology 1993, 43:2331-2335.

179. de Klerk OL, Willemsen AT, Roosink M, Bartels AL, Hendrikse NH, Bosker FJ, den Boer JA: Locally increased P-glycoprotein function in major depression: a PET study with [11C]verapamil as a probe for P-glycoprotein function in the blood-brain barrier. Int I Neuropsychopharmacol 2009 12:895-904.

180. Fujii T, Ota M, Hori H, Sasayama D, Hattori K, Teraishi T, Yamamoto N, Hashikura M, Tatsumi M, Higuchi T, Kunugi H: Association between the functional polymorphism (C3435T) of the gene encoding P-glycoprotein $(A B C B 1)$ and major depressive disorder in the Japanese population. J Psychiatr Res 2012, 46:555-559.

181. de Klerk OL, Bosker FJ, Willemsen AT, Van Waarde A, Visser AK, de Jager T, Dagyte G, den Boer JA, Dierckx RA, Meerlo P: Chronic stress and antidepressant treatment have opposite effects on P-glycoprotein at the blood-brain barrier: an experimental PET study in rats. J Psychopharmacol 2010, 24:1237-1242.

182. Lavoie KL, Pelletier R, Arsenault A, Dupuis J, Bacon SL: Association between clinical depression and endothelial function measured by forearm hyperemic reactivity. Psychosom Med 2010, 72:20-26.

183. Politi P, Brondino N, Emanuele E: Increased proapoptotic serum activity in patients with chronic mood disorders. Arch Med Res 2008, 39:242-245.

184. Serlin Y, Levy J, Shalev H: Vascular pathology and blood-brain barrier disruption in cognitive and psychiatric complications of type 2 diabetes mellitus. Cardiovasc Psychiatry Neurol 2011, 2011:609202. 
185. Abbott NJ, Ronnback L, Hansson E: Astrocyte-endothelial interactions at the blood-brain barrier. Nat Rev Neurosci 2006, 7:41-53.

186. Gudmundsson P, Skoog I, Waern M, Blennow K, P.Isson S, Rosengren L, Gustafson D: The relationship between cerebrospinal fluid biomarkers and depression in elderly women. Am J Geriatr Psychiatry 2007, 15:832.

187. Bechter K, Reiber H, Herzog S, Fuchs D, Tumani H, Maxeiner HG: Cerebrospinal fluid analysis in affective and schizophrenic spectrum disorders: identification of subgroups with immune responses and blood-CSF barrier dysfunction. J Psychiatr Res 2010, 44:321-330.

188. Niklasson F, Agren H: Brain energy metabolism and blood-brain barrier permeability in depressive patients: analyses of creatine, creatinine, urate, and albumin in CSF and blood. Biol Psychiatry 1984, 19:1183-1206.

189. Schroeter ML, Abdul-Khaliq H, Krebs M, Diefenbacher A, Blasig IE: Serum markers support disease-specific glial pathology in major depression. J Affect Disord 2008, 111:271-280.

190. Falcone T, Fazio V, Lee C, Simon B, Franco K, Marchi N, Janigro D: Serum S100B: a potential biomarker for suicidality in adolescents? PLOS ONE 2010, 5:e11089.

191. Miller BJ, Buckley P, Seabolt W, Mellor A, Kirkpatrick B: Meta-analysis of cytokine alterations in schizophrenia: clinical status and antipsychotic effects. Biol Psychiatry 2011, 70:663-671.

192. Hawkins BT, Sykes DB, Miller DS: Rapid, reversible modulation of bloodbrain barrier P-glycoprotein transport activity by vascular endothelial growth factor. J Neurosci 2010, 30:1417-1425.

193. Förstermann U: Janus-faced role of endothelial NO synthase in vascular disease: uncoupling of oxygen reduction from NO synthesis and its pharmacological reversal. Biol Chem 2006, 387:1521-1533.

194. Wiencken A, Casagrande V: Endothelial nitric oxide synthetase (eNOS) in astrocytes: another source of nitric oxide in neocortex. Glia 1999, 26:280

195. Iwase K, Miyanaka K, Shimizu A, Nagasaki A, Gotoh T, Mori M, Takiguchi M: Induction of endothelial nitric-oxide synthase in rat brain astrocytes by systemic lipopolysaccharide treatment. J Biol Chem 2000, 275:11929-11933.

196. Carreras MC, Franco MC, Finocchietto PV, Converso DP: Antico Arciuch VG, Holod S, Peralta JG, Poderoso JJ: The biological significance of mtNOS modulation. Front Biosci 2007, 12:1041-1048.

197. Lacza Z, Puskar M, Fiqueroa JP, Zhang J, Rajapakse N, Busija DW: Mitochondrial nitric oxide synthase is constitutively active and is functionally upregulated in hypoxia. Free Radic Biol Med 2001, 31:1609-1615.

198. Andrew PJ, Mayer B: Enzymatic function of nitric oxide synthases. Cardiovasc Res 1999, 43:521-531.

199. Galea E, Feinstein DL, Reis DJ: Induction of calcium-independent nitric oxide synthase activity in primary rat glial cultures. Proc Natl Acad Sci USA 1992, 89:10945-10949.

200. Chuang YC: Mitochondrial dysfunction and oxidative stress in seizureinduced neuronal cell death. Acta Neurol Taiwan 2010, 19:3-15.

201. Joynt KE, Whellan DJ, O'Connor CM: Depression and cardiovascular disease: mechanisms of interaction. Biol Psychiatry 2003, 54:248-261.

202. Sun CW, Falck JR, Okamoto H, Harder DR, Roman RJ: Role of cGMP versus 20-HETE in the vasodilator response to nitric oxide in rat cerebral arteries. Am J Physiol Heart Circ Physiol 2000, 279:H339-H350.

203. Attwell D, Buchan AM, Charpak S, Lauritzen M, Macvicar BA, Newman EA Glial and neuronal control of brain blood flow. Nature 2010, 468:232-243.

204. Liu WW, Huang PL: Cardiovascular roles of nitric oxide: a review of insights from nitric oxide synthase gene disrupted mice. Cardiovasc Res 2008, 77:19-29.

205. Szabo C, Ischiropoulos H, Radi R: Peroxynitrite: biochemistry, pathophysiology and development of therapeutics. Nat Rev Drug Discov 2007, 6:662-680

206. Antoniades C, Shirodaria C, Warrick N, Cai S, de Bono J, Lee J, Leeson P, Neubauer S, Ratnatunga C, Pillai R, Refsum H, Channon KM: 5 methyltetrahydrofolate rapidly improves endothelial function and decreases superoxide production in human vessels: effects on vascular tetrahydrobiopterin availability and endothelial nitric oxide synthase coupling. Circulation 2006, 114:1193-1201.

207. Chrapko W, Jurasz P, Radomski MW, Archer SL, Newman SC, Baker G, Lara N, Le Melledo JM: Alteration of decreased plasma NO metabolites and platelet NO synthase activity by paroxetine in depressed patients. Neuropsychopharmacology 2006, 31:1286-1293.

208. Chrapko WE, Jurasz P, Radomski MW, Lara N, Archer SL, Le Melledo JM: Decreased platelet nitric oxide synthase activity and plasma nitric oxide metabolites in major depressive disorder. Biol Psychiatry 2004, 56:129-134.
209. Khan M, Sakakima H, Dhammu TS, Shunmugavel A, Im YB, Gilg AG, Singh AK, Singh I: S-nitrosoglutathione reduces oxidative injury and promotes mechanisms of neurorepair following traumatic brain injury in rats. J Neuroinflammation 2011, 8:78.

210. Huang Z, Huang PL, Panahian N, Dalkara T, Fishman MC, Moskowitz MA: Effects of cerebral ischemia in mice deficient in neuronal nitric oxide synthase. Science 1994, 265:1883-1885.

211. ladecola C, Zhang F, Casey R, Nagayama M, Ross ME: Delayed reduction of ischemic brain injury and neurological deficits in mice lacking the inducible nitric oxide synthase gene. J Neurosci 1997, 17:9157-9164.

212. Huang Z, Huang PL, Ma J, Meng W, Ayata C, Fishman MC, Moskowitz MA: Enlarged infarcts in endothelial nitric oxide synthase knockout mice are attenuated by nitro-L-arginine. J Cereb Blood Flow Metab 1996, 16:981-987.

213. Shimizu-Sasamata M, Bosque-Hamilton P, Huang PL, Moskowitz MA, Lo EH: Attenuated neurotransmitter release and spreading depression-like depolarizations after focal ischemia in mutant mice with disrupted type I nitric oxide synthase gene. J Neurosci 1998, 18:9564-9571.

214. Samdani AF, Dawson TM, Dawson VL: Nitric oxide synthase in models of focal ischemia. Stroke 1997, 28:1283-1288.

215. Lu Q, Xia N, Xu H, Guo L, Wenzel P, Daiber A, Munzel T, Forstermann U, Li $\mathrm{H}$ : Betulinic acid protects against cerebral ischemia-reperfusion injury in mice by reducing oxidative and nitrosative stress. Nitric Oxide 2011, 24:132-138.

216. Masano T, Kawashima S, Toh R, Satomi-Kobayashi S, Shinohara M, Takaya T, Sasaki N, Takeda M, Tawa H, Yamashita T, Yokoyama M, Hirata K: Beneficial effects of exogenous tetrahydrobiopterin on left ventricular remodeling after myocardial infarction in rats: the possible role of oxidative stress caused by uncoupled endothelial nitric oxide synthase. Circ J 2008, 72:1512-1519

217. Papakostas Gl, Shelton RC, Zajecka JM, Etemad B, Rickels K, Clain A, Baer L, Dalton ED, Sacco GR, Schoenfeld D, Pencina M, Meisner A, Bottiglieri T, Nelson E, Mischoulon D, Alpert JE, Barbee JG, Zisook S, Fava M: Lmethylfolate as adjunctive therapy for SSRI-resistant major depression: results of two randomized, double-blind, parallel-sequential trials. Am J Psychiatry 2012, 169:1267-1274.

218. Srivastava K, Bath PMW, Bayraktutan U: Current therapeutic strategies to mitigate the eNOS dysfunction in ischaemic stroke. Cell Mol Neurobiol 2012, 32:319-336

219. Aliev G, Obrenovich ME, Tabrez S, Jabir NR, Reddy VP, Li Y, Burnstock G, Cacabelos R, Kamal MA: Link between cancer and alzheimer disease via oxidative stress induced by nitric oxide-dependent mitochondrial DNA overproliferation and deletion. Oxid Med Cell Longev 2013, 2013:962984.

220. Aliev G, Palacios HH, Walrafen B, Lipsitt AE, Obrenovich ME, Morales L: Brain mitochondria as a primary target in the development of treatment strategies for Alzheimer disease. Int J Biochem Cell Biol 2009, 41:1989-2004

221. Aliev G, Seyidova D, Lamb BT, Obrenovich ME, Siedlak SL, Vinters HV, Friedland RP, LaManna JC, Smith MA, Perry G: Mitochondria and vascular lesions as a central target for the development of Alzheimer's disease and Alzheimer disease-like pathology in transgenic mice. Neurol Res 2003 25:665-674

222. Aliev G, Smith MA, Obrenovich ME, de la Torre JC, Perry G: Role of vascular hypoperfusion-induced oxidative stress and mitochondria failure in the pathogenesis of Azheimer disease. Neurotox Res 2003, 5:491-504

223. Ofek K, Schoknecht K, Melamed-Book N, Heinemann U, Friedman A, Soreq $\mathrm{H}$ : Fluoxetine induces vasodilatation of cerebral arterioles by comodulating NO/muscarinic signalling. J Cell Mol Med 2012, 16:2736-2744

224. Cisse S, Schipper HM: Isolation of pseudoperoxidase-positive astrocyte granules from intact rat brain and cysteamine-treated neuroglial cultures. Brain Res 1993, 615:141-146.

225. Gray DA, Woulfe J: Lipofuscin and aging: a matter of toxic waste. SCi Aging Knowledge Environ 2005, 2005:re1.

226. Hirai K, Aliev G, Nunomura A, Fujioka H, Russell RL, Atwood CS, Johnson AB, Kress $Y$, Vinters HV, Tabaton M, Shimohama S, Cash AD, Siedlak SL, Harris PL, Jones PK, Petersen RB, Perry G, Smith MA: Mitochondrial abnormalities in Alzheimer's disease. J Neurosci 2001, 21:3017-3023.

227. Joris I, Billingham M, Underwood J, Majno G: Lipofuscin and lipid oxidation in human coronary endothelium. Cardiovasc Pathol 1998, 7:75-85.

228. Keller JN, Dimayuga E, Chen Q, Thorpe J, Gee J, Ding Q: Autophagy, proteasomes, lipofuscin, and oxidative stress in the aging brain. Int J Biochem Cell Biol 2004, 36:2376-2391. 
229. Ikenouchi-Sugita A, Yoshimura R, Kishi T, Umene-Nakano W, Hori H, Hayashi K, Katsuki A, Ueda N, Iwata N, Nakamura J: Three polymorphisms of the eNOS gene and plasma levels of metabolites of nitric oxide in depressed Japanese patients: a preliminary report. Hum Psychopharmacol 2011, 26:531-534

230. Zeman M, Jachymova M, Jirak R, Vecka M, Tvrzicka E, Stankova B, Zak A: Polymorphisms of genes for brain-derived neurotrophic factor, methylenetetrahydrofolate reductase, tyrosine hydroxylase, and endothelial nitric oxide synthase in depression and metabolic syndrome. Folia Biol (Praha) 2010, 56:19-26.

231. Rajkowska G, Stockmeier CA: Astrocyte pathology in major depressive disorder: insights from human postmortem brain tissue. Curr Drug Targets 2013, 4:1225-1236

232. Cotter D, Hudson L, Landau S: Evidence for orbitofrontal pathology in bipolar disorder and major depression, but not in schizophrenia. Bipolar Disord 2005, 7:358-369.

233. Cotter D, Mackay D, Beasley C, Kerwin R, Everall I: Reduced glial density and neuronal volume in major depressive disorder and schizophrenia in the anterior cingulate cortex. Schizophr Res 2000, 41:106

234. Cotter D, Mackay D, Chana G, Beasley C, Landau S, Everall IP: Reduced neuronal size and glial cell density in area 9 of the dorsolateral prefrontal cortex in subjects with major depressive disorder. Cereb Cortex 2002, 12:386-394.

235. Cotter D, Mackay D, Landau S, Kerwin R, Everall I: Reduced glial cell density and neuronal size in the anterior cingulate cortex in major depressive disorder. Arch Gen Psychiatry 2001, 58:545-553.

236. Cotter DR, Pariante CM, Everall IP: Glial cell abnormalities in major psychiatric disorders: the evidence and implications. Brain Res Bull 2001, 55:585-595.

237. Kettenmann H, Hanisch UK, Noda M, Verkhratsky A: Physiology of microglia. Physiol Rev 2011, 91:461-553.

238. Schwartz M, Butovsky O, Bruck W, Hanisch UK: Microglial phenotype: is the commitment reversible? Trends Neurosci 2006, 29:68-74.

239. Bayer TA, Buslei R, Havas L, Falkai P: Evidence for activation of microglia in patients with psychiatric illnesses. Neurosci Lett 1999, 271:126-128.

240. Miller AH, Maletic V, Raison CL: Inflammation and its discontents: the role of cytokines in the pathophysiology of major depression. Biol Psychiatry 2009, 65:732-741.

241. Liu H, Luiten PG, Eisel UL, Dejongste MJ, Schoemaker RG: Depression after myocardial infarction: TNF-alpha-induced alterations of the blood-brain barrier and its putative therapeutic implications. Neurosci Biobehav Rev 2013, 37:561-572.

242. Rege S, Hodgkinson SJ: Immune dysregulation and autoimmunity in bipolar disorder: synthesis of the evidence and its clinical application. Aust N Z J Psychiatry. In press.

243. Henninger DD, Panes J, Eppihimer M, Russell J, Gerritsen M, Anderson DC, Granger DN: Cytokine-induced VCAM-1 and ICAM-1 expression in different organs of the mouse. J Immunol 1997, 158:1825-1832.

244. Haraldsen G, Kvale D, Lien B, Farstad IN, Brandtzaeg P: Cytokine-regulated expression of E-selectin, intercellular adhesion molecule-1 (ICAM-1), and vascular cell adhesion molecule-1 (VCAM-1) in human microvascular endothelial cells. J Immunol 1996, 156:2558-2565.

245. Becker JC, Dummer R, Hartmann AA, Burg G, Schmidt RE: Shedding of ICAM-1 from human melanoma cell lines induced by IFN-gamma and tumor necrosis factor-alpha. Functional consequences on cell-mediated cytotoxicity. J Immunol 1991, 147:4398-4401.

246. Dietrich JB: The adhesion molecule ICAM-1 and its regulation in relation with the blood-brain barrier. J Neuroimmunol 2002, 128:58-68.

247. Isogai N, Tanaka H, Asamura S: Thrombosis and altered expression of intercellular adhesion molecule-1 (ICAM-1) after avulsion injury in rat vessels. J Hand Surg (Br) 2004, 29:230-234.

248. Pu H, Tian J, Flora G, Lee YW, Nath A, Hennig B, Toborek M: HIV-1 Tat protein upregulates inflammatory mediators and induces monocyte invasion into the brain. Mol Cell Neurosci 2003, 24:224-237.

249. Zameer A, Hoffman SA: Increased ICAM-1 and VCAM-1 expression in the brains of autoimmune mice. J Neuroimmunol 2003, 142:67-74.

250. Onore CE, Nordahl CW, Young GS, Van de Water JA, Rogers SJ, Ashwood P: Levels of soluble platelet endothelial cell adhesion molecule-1 and P-selectin are decreased in children with autism spectrum disorder. Biol Psychiatry 2012, 72:1020-1025.

251. Li J, Ye L, Wang X, Liu J, Wang Y, Zhou Y, Ho W: (-)-Epigallocatechin gallate inhibits endotoxin-induced expression of inflammatory cytokines in human cerebral microvascular endothelial cells. J Neuroinflammation 2012, 9:161.

252. Schaefer M, Horn M, Schmidt F, Schmid-Wendtner MH, Volkenandt M, Ackenheil M, Mueller N, Schwarz MJ: Correlation between sICAM-1 and depressive symptoms during adjuvant treatment of melanoma with interferon-alpha. Brain Behav Immun 2004, 18:555-562.

253. Ott M, Gogvadze V, Orrenius S, Zhivotovsky B: Mitochondria, oxidative stress and cell death. Apoptosis 2007, 12:913-922.

254. Rao KV, Brahmbhatt M, Norenberg MD: Microglia contribute to ammoniainduced astrocyte swelling in culture. Metab Brain Dis 2013, 28:139-143.

255. Karolewicz B, Szebeni K, Gilmore T, Maciag D, Stockmeier CA, Ordway GA: Elevated levels of NR2A and PSD-95 in the lateral amygdala in depression. Int J Neuropsychopharmacol 2009, 12:143-153.

256. Scott GS, Bowman SR, Smith T, Flower RJ, Bolton C: Glutamate-stimulated peroxynitrite production in a brain-derived endothelial cell line is dependent on N-methyl-D-aspartate (NMDA) receptor activation. Biochem Pharmacol 2007, 73:228-236.

257. Moura DS, Sultan S, Georgin-Lavialle S, Barete S, Lortholary O, Gaillard R, Hermine $\mathrm{O}$ : Evidence for cognitive impairment in mastocytosis: prevalence, features and correlations to depression. PLoS ONE 2012, 7:e39468.

258. van Berckel BN, Bossong MG, Boellaard R, Kloet R, Schuitemaker A, Caspers E, Luurtsema G, Windhorst AD, Cahn W, Lammertsma AA, Kahn RS: Microglia activation in recent-onset schizophrenia: a quantitative (R)-[11C]PK11195 positron emission tomography study. Biol Psychiatry 2008, 64:820-822.

259. Doorduin J, de Vries EF, Willemsen AT, de Groot JC, Dierckx RA, Klein HC: Neuroinflammation in schizophrenia-related psychosis: a PET study. J Nucl Med 2009, 50:1801-1807.

260. Takano A, Arakawa R, Ito H, Tateno A, Takahashi H, Matsumoto R, Okubo Y, Suhara T: Peripheral benzodiazepine receptors in patients with chronic schizophrenia: a PET study with [11C]DAA1106. Int J Neuropsychopharmacol 2010, 13:943-950.

doi:10.1186/1742-2094-10-142

Cite this article as: Najjar et al.: Neurovascular unit dysfunction with blood-brain barrier hyperpermeability contributes to major depressive disorder: a review of clinical and experimental evidence. Journal of Neuroinflammation 2013 10:142.

\section{Submit your next manuscript to BioMed Central and take full advantage of:}

- Convenient online submission

- Thorough peer review

- No space constraints or color figure charges

- Immediate publication on acceptance

- Inclusion in PubMed, CAS, Scopus and Google Scholar

- Research which is freely available for redistribution 